\title{
Nature of Metal-Drug Bond in Some Antitumor Active Complexes of Coinage Metal lons
}

\author{
Bahareh Naderizadeh and Mehdi Bayat*
}

Cite This: ACS Omega 2020, 5, 26999-27015

Read Online

ABSTRACT: N-Heterocyclic carbene and phosphine can be labeled as solid $\sigma$-donor ligands and can contribute to stable complexes. In addition, the constructed complex can accommodate a wide variety of applications, such as pharmaceutical products. In the light of this, a theoretical analysis was carried out on the existence of metal-drug interactions of group 11 metal ions in coordination with symmetrical unsaturated $\mathrm{N}$-heterocyclic carbenes $\left[\mathrm{NHC}(\mathrm{R})\left(\mathrm{R}^{\prime}\right)\right]$ and monodentate phosphine $\left(\mathrm{PR}_{3}\right)$. The $\mathrm{R}$ substitutes on $\mathrm{N}$ atoms in $\mathrm{NHC}$ and phosphines are identical, and $\mathrm{R}^{\prime}$ substitutes are located on two noncarbenic carbon atoms ( $\mathrm{C} 4$ and $\mathrm{C} 5)$ in the heterocycle complexes. All complexes are in general formula, [Tgt $\rightarrow \mathrm{ML}]$ \{where $\mathrm{M}=\mathrm{Cu}(\mathrm{I})$, $\operatorname{Ag}(\mathrm{I}), \mathrm{Au}(\mathrm{I}), \mathrm{Tgt}=2,3,4,6$-tetra- $O$-acetyl-1-thio- $\beta$-D-glucopyranoside, $\mathrm{L}=\left[\mathrm{NHC}(\mathrm{R})\left(\mathrm{R}^{\prime}\right)\right]$, and $\mathrm{PR}_{3} ; \mathrm{R}=\mathrm{F}, \mathrm{Cl}, \mathrm{Br}, \mathrm{H}, \mathrm{CH}_{3}, \mathrm{C}_{2} \mathrm{H}_{5}, \mathrm{SiH}_{3}, 2,6-$

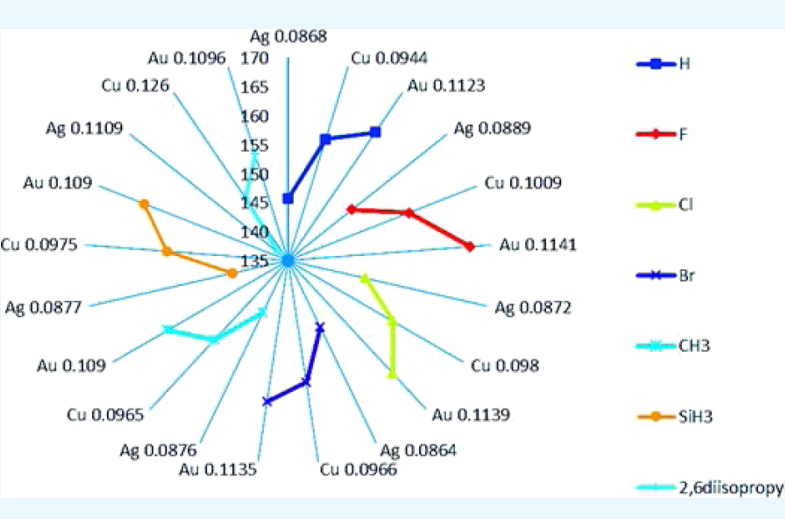
diisopropylphenyl; $\mathrm{R}^{\prime}=\mathrm{H}$ and $\left.\mathrm{Ph}\right\}$ at the PBE-D3/def2-TZVP level of theory. Findings show greater tolerance for the release of drugs in the presence of $\mathrm{Ag}(\mathrm{I})$ metal ions than the other metal ions studied here. Applying natural bond orbital (NBO), atoms in molecules (AIMs), energy decomposition analysis (EDA), and extended transition-state natural orbital for chemical valence (ETS-NOCV) analysis have been researched in order to ascertain the nature of $\mathrm{M} \leftarrow \mathrm{S}$ and $\mathrm{M} \leftarrow \mathrm{C}(\mathrm{M} \leftarrow \mathrm{P})$ bonds in the complexes. Results have shown that $\sigma$ donation from $\mathrm{S}$ to $\mathrm{M}$ atoms in [Tgt $\left.\rightarrow \mathrm{MPR}_{3}\right]$ complexes is better and the $\pi$ acceptor is weaker than the corresponding [Tgt $\rightarrow$ MNHC $\left.(\mathrm{R})\left(\mathrm{R}^{\prime}\right)\right]$ complexes.

\section{INTRODUCTION}

$\mathrm{N}-$ Heterocyclic carbenes (NHCs), which can be considered as ligands featuring a singlet carbon donor, possess a single lonepair orbital at the carbon atom described as carbon (II). Furthermore, they are also known as potent $\sigma$-donor ligands in metal transition complexes. ${ }^{1-3}$ Taking this into account, the strong NHC $\sigma$-donor properties will contribute to the development of metal-NHC complexes with high chemical and thermal stability. ${ }^{4,5}$

Such complexes were initially synthesized by Öfele ${ }^{6}$ and Wanzlick ${ }^{7}$ nearly at the same time in 1968. In addition, in $19911^{8}$ the first free carbene has been isolated by Arduengo. Nowadays, metal-NHC complexes have already been known to be a major area of research for the development of new metallodrugs because of their high stability and ease of derivatives. It is worth noting that the biological potential of metal-NHC complexes has been considered to be one of the most important areas in bio-organometallic chemistry. ${ }^{9-19}$

Regarding this subject, over the last few years, a lot of research has been done, a substantial number of papers have been published, and plenty of metal-transition complexes containing NHC ligands have been identified as possible antitumor products. $^{9-16,18,21-24}$

Cisplatin and other platinum species have also been used in clinics considered effective anticancer medicines. The side effects, however, prompted scientists to look for new anticancer medicines. Recently, nonplatinum medications have gained a great deal of coverage as cancer chemotherapy to discover novel therapies of efficacy and clinical profiles. ${ }^{20}$

By virtue of the fact that the NHCs have potent $\sigma$-donating potential to be bound to metal ions like phosphine, Nheterocyclic carbene complexes have been considered as good alternatives to phosphine. $^{21}$ In addition, imidazolium salt precursors are also more easily synthesized compared to phosphines. In addition, when NHC ligands and other metal ions are combined, the consequence is an interesting biological profile. In comparison, there seems to be a different process for metal-NHC complexes than platinum-based drugs that can hardly reach DNA. ${ }^{20,22-25}$

On the other hand, tertiary phosphines $\left(\mathrm{PR}_{3}\right)$ are accessible ligands of numerous transition metals and nontransitional metal ions. By making modifications in R groups, the electronic and

Received: April 1, 2020

Accepted: September 29, 2020

Published: October 15, 2020 
steric properties of phosphines can be modified systematically and consistently. In contrast to amines, phosphines are administered with unmatched features; that is, they act as $\pi$ acids. Additionally, phosphine ligands can stabilize transitionmetal ions in low oxidation states. ${ }^{26}$ A number of theoretical studies on the structure and function of metal ligand bonding in transition metals and nontransitional NHC complexes have recently been published. ${ }^{20-27}$

In this content, for first time, a comparative theoretical study on the effects of changing ligands $\{\mathrm{N}$-heterocyclic carbenes $\mathrm{NHC}(\mathrm{R})\left(\mathrm{R}^{\prime}\right)$ and monodentate phosphine $\mathrm{PR}_{3}$ and also metal ions $[\mathrm{Cu}(\mathrm{I}), \operatorname{Ag}(\mathrm{I})$, and $\mathrm{Au}(\mathrm{I})]$ on drug release and the nature of the metal-drug bond in some antitumor active complexes of coinage metal ions with $\mathrm{N}$-heterocyclic carbenes [NHC(R)$\left.\left(\mathrm{R}^{\prime}\right)\right]$ and monodentate phosphine $\left(\mathrm{PR}_{3}\right)$ with general formula $[\mathrm{Tgt} \rightarrow \mathrm{ML}],[\mathrm{M}=\mathrm{Cu}(\mathrm{I}), \mathrm{Ag}(\mathrm{I}), \mathrm{Au}(\mathrm{I})$; Tgt $=2,3,4,6$-tetra- $O$ acetyl-1-thio- $\beta$-D-glucopyranoside; $\mathrm{R}=\mathrm{F}, \mathrm{Cl}, \mathrm{Br}, \mathrm{H}, \mathrm{CH}_{3}, \mathrm{C}_{2} \mathrm{H}_{5}$, $\mathrm{SiH}_{3}$, 2,6-diisopropylphenyl; $\mathrm{R}^{\prime}=\mathrm{H}$ and $\left.\mathrm{Ph}\right]$ at the PBE-D3/ def2-TZVP level of theory is reported. In addition, $R^{\prime}$ substitutes are given on two noncarbenic carbon atoms $\left(C_{4}\right.$ and $\left.C_{5}\right)$ in NHC.

\section{COMPUTATIONAL DETAILS}

In this study, the $[\mathrm{Tgt} \rightarrow \mathrm{Au}(\mathrm{IPr})][\mathrm{IPr}=$ bis- $(2,6-$ diisopropylphenyl)-imidazolin-2-ylidene] complex was applied using eight density functional methods, namely, B3LYP, BLYP, BP86, Cam-B3LYP, M06, M05-2X, M06-2X, and PBE in combination with D3 dispersion corrections is examined. Furthermore, the obtained structural results were compared with the equivalent experimental values gained by the X-ray structure. $^{28}$

Results obtained using rms methodological findings suggest that PBE-D3, the most relevant function of the abovementioned methods, has the largest association between quantitative and experimental structural data (see Table 1).

Table 1. Comparison between the Performances of Eight Density Functional Methods of $\mathrm{Au}-\mathrm{C}$ and $\mathrm{Au}-\mathrm{S}$ Bond Lengths $(\AA)$ of $[\mathrm{Tgt} \rightarrow \mathrm{Au}(\mathrm{NHC}(2,6-\mathrm{Diisopropyl}$ Phenyl)] Complex

\begin{tabular}{lccc}
\multicolumn{1}{c}{ method } & $\mathrm{Au}-\mathrm{C}(\AA)$ & $\mathrm{Au}-\mathrm{S}(\AA)$ & $\mathrm{rms}$ \\
\hline B3LYP-D3 & 2.027 & 2.328 & 0.040 \\
BLYP-D3 & 2.032 & 2.343 & 0.051 \\
BP86-D3 & 2.022 & 2.313 & 0.031 \\
CAM-B3LYP-D3 & 2.016 & 2.318 & 0.030 \\
M06-D3 & 2.026 & 2.333 & 0.043 \\
M05-2X-D3 & 2.004 & 2.309 & 0.020 \\
M06-2X-D3 & 2.047 & 2.341 & 0.057 \\
PBE-D3 & 2.008 & 2.314 & 0.025 \\
Exp & 1.986 & 2.287 & \\
${ }^{a}$ Data derived from ref 29. & & & \\
\hline
\end{tabular}

In this article, three types of complexes are reported with the formulas $\left[\mathrm{Tgt} \rightarrow \mathrm{MNHC}(\mathrm{R})\left(\mathrm{R}^{\prime}\right)\right]$ and $\left[\mathrm{Tgt} \rightarrow \mathrm{MP}(\mathrm{R})_{3}\right][\mathrm{M}=$ $\mathrm{Cu}(\mathrm{I}), \mathrm{Ag}(\mathrm{I}), \mathrm{Au}(\mathrm{I}) ; \mathrm{R}=\mathrm{F}, \mathrm{Cl}, \mathrm{Br}, \mathrm{H}, \mathrm{CH}_{3}, \mathrm{C}_{2} \mathrm{H}_{5}, \mathrm{SiH}_{3}, 2,6-$ diisopropylphenyl; $\mathrm{R}^{\prime}=\mathrm{H}$ and $\mathrm{Ph}$. Additionally, these substituents are given in the heterocycle $\left(\mathrm{C}_{4}\right.$ and $\left.\mathrm{C}_{5}\right)$ on two noncarbenic carbon atoms (see Scheme 1).

All calculations were carried out at the PBE-D3/def2TZVP level of theory using the GAUSSIAN 09 software. ${ }^{29}$ The vibrational frequency study reveals that the optimized structures
Scheme 1. Schematic Representation of the [Tgt $\rightarrow$ $\left.\operatorname{MNHC}(\mathbf{R})\left(\mathbf{R}^{\prime}\right)\right]$ and $\left[\mathbf{T g t} \rightarrow \operatorname{MP}(\mathbf{R})_{3}\right]$ Complexes $[\mathbf{M}=$ $\mathrm{Cu}(\mathrm{I}), \operatorname{Ag}(\mathrm{I}), \mathrm{Au}(\mathrm{I}) ; \mathrm{R}=\mathrm{F}, \mathrm{Cl}, \mathrm{Br}, \mathrm{H}, \mathrm{CH}_{3}, \mathrm{C}_{2} \mathrm{H}_{5}, \mathrm{SiH}_{3}, 2,6-$ Diisopropylphenyl; $\mathrm{R}^{\prime}=\mathrm{H}$ and $\mathrm{Ph}$ ]<smiles>[R]C1=C([R])N([R])C([M]SC2OC(COC(C)=O)C(OC(C)=O)C(OC(C)=O)C2O)N1[R]</smiles><smiles>[R18]NSC1OC(COC(C)=O)C(OC(C)=O)C(OC(C)=O)C1OC(C)=O</smiles>

$$
\begin{aligned}
& \mathrm{M}=\mathrm{Cu}, \mathrm{Ag}, \mathrm{Au} \\
& \mathrm{R}=\mathrm{H}, \mathrm{F}, \mathrm{Cl}, \mathrm{Br}, \mathrm{CH}_{3}, \mathrm{C}_{2} \mathrm{H}_{5}, \mathrm{SiH}_{3}, 2,6 \text {-diisopropylphenyl } \\
& \mathrm{R}^{\prime}=\mathrm{H}, \mathrm{Ph}
\end{aligned}
$$

at stationary points, determined at the same theoretical level, correspond to the local minima with no imaginary frequency.

In order to obtain bond properties, the AIM 2010 package was used. To perform AIM calculations, wave function files were generated from Gaussian output files at the PBE-D3/def2TZVP level of theory. ${ }^{30}$

In this context, the objective was to conduct a natural bond orbital (NBO) analysis ${ }^{31}$ with the GAUSSIAN 09 internal module at the theoretical level ${ }^{32}$ described above. Energy decomposition analysis (EDA) measurements have been carried out to evaluate the nature of the bonding of $S \rightarrow M$ at the BP86D3/TZ2P (ZORA)/PBE-D3/def2 TZVP level of theory using the ADF 2009.01 software package.

\section{RESULTS AND DISCUSSION}

3.1. Structural Studies. Figures $1-3$ display the optimized configurations of $\left[\mathrm{Tgt} \rightarrow \mathrm{MNHC}(\mathrm{R})\left(\mathrm{R}^{\prime}\right)\right]$ and [Tgt $\rightarrow \mathrm{MPR} 3$ ] $[\mathrm{M}=\mathrm{Cu}(\mathrm{I}), \mathrm{Ag}(\mathrm{I}), \mathrm{Au}(\mathrm{I}) ; \mathrm{R}=\mathrm{F}, \mathrm{Cl}, \mathrm{Br}, \mathrm{H}, \mathrm{CH} 3, \mathrm{C} 2 \mathrm{H} 5, \mathrm{SiH} 3$, 2,6-diisopropylphenyl; $\mathrm{R}^{\prime}=\mathrm{H}$ and $\mathrm{Ph}$ ] [as these substitutes are given on two noncarbenic carbon atoms $\left(\mathrm{C}_{4}\right.$ and $\left.\mathrm{C}_{5}\right)$ in the heterocycle complexes] at the PBE-D3/def2-TZVP level of theory. As can be seen in Figures 1-3 and Table S1, the length of the $\mathrm{M} \leftarrow \mathrm{S}$ bond is larger than the length of the $\mathrm{M} \leftarrow \mathrm{C}$ bond in the $\left[\right.$ Tgt $\left.\rightarrow \operatorname{MNHC}(\mathrm{R})\left(\mathrm{R}^{\prime}\right)\right]$ complexes, with different substituents. For example, in $[\mathrm{Tgt} \rightarrow \mathrm{CuNHC}(\mathrm{H})(\mathrm{H})]$ the value of $\mathrm{M} \leftarrow \mathrm{S}$ and $\mathrm{M} \leftarrow \mathrm{C}$ bonds is $2.17 \AA$ and $1.89 \AA$, respectively. In addition, by changing the substituent $\mathrm{R}$ from $\mathrm{F}$ to $\mathrm{Br}$, the bond lengths of $\mathrm{M} \leftarrow \mathrm{S}$ and $\mathrm{M} \leftarrow \mathrm{C}$ are slightly increased (see Figure $1-3$ and Table S1).

On the other hand, by changing the $\mathrm{R}$ substituent from $\mathrm{F}$ to $\mathrm{Br}$, in $\left[\mathrm{Tgt} \rightarrow \mathrm{MPR}_{3}\right]$ complexes which are similar to $\mathrm{M} \leftarrow \mathrm{S}$ and $\mathrm{M} \leftarrow \mathrm{C}$ bond lengths in $\left[\mathrm{Tgt} \rightarrow \mathrm{MNHC}(\mathrm{R})\left(\mathrm{R}^{\prime}\right)\right]$ complexes, 

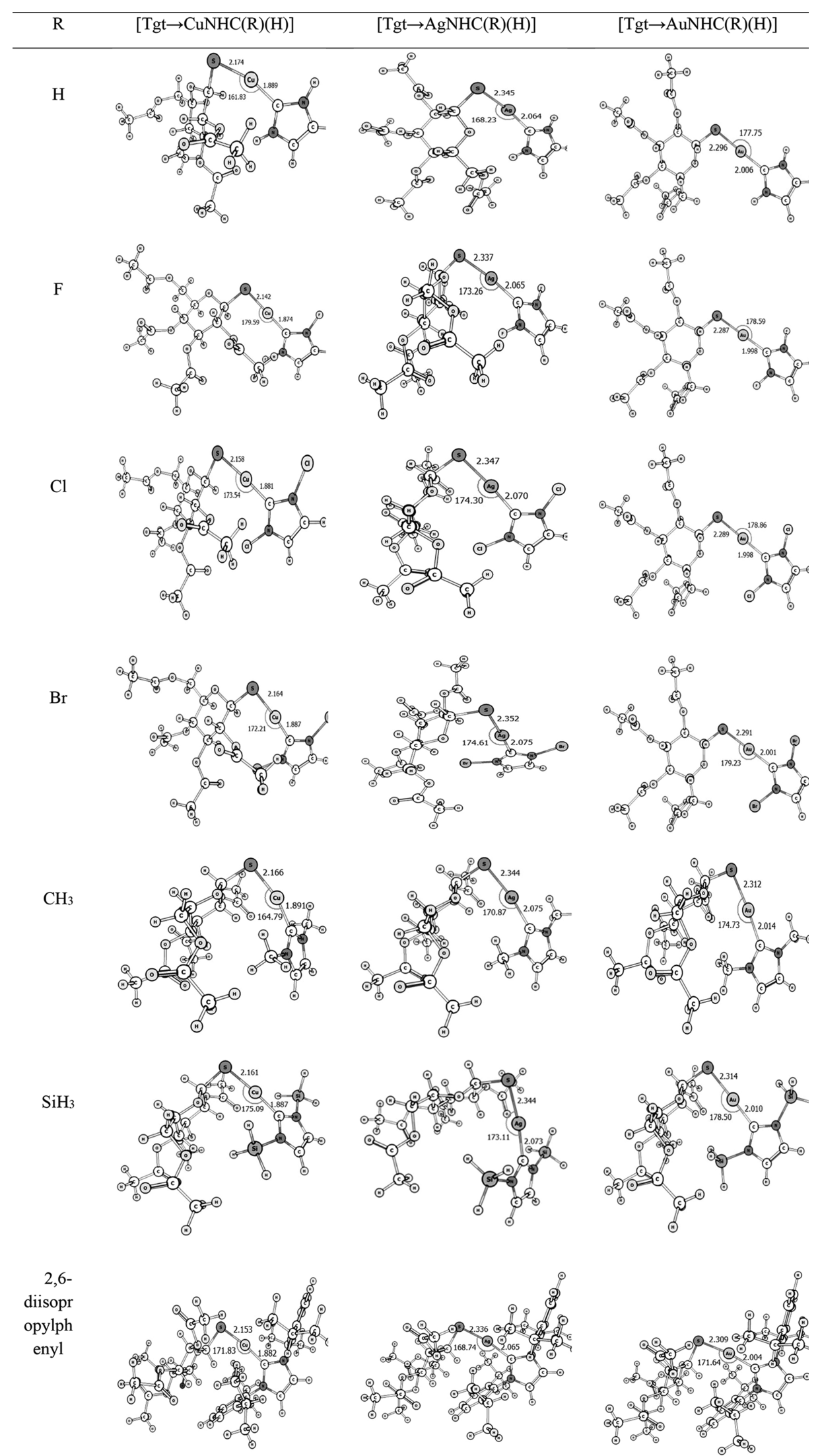

Figure 1. Optimized structures of $[\mathrm{Tgt} \rightarrow \operatorname{MNHC}(\mathrm{R})(\mathrm{H})]\left[\mathrm{M}=\mathrm{Cu}(\mathrm{I}), \mathrm{Ag}(\mathrm{I}), \mathrm{Au}(\mathrm{I}) ; \mathrm{R}=\mathrm{F}, \mathrm{Cl}, \mathrm{Br}, \mathrm{H}, \mathrm{CH}_{3}, \mathrm{SiH}_{3}\right.$, 2,6-diisopropylphenyl; $\left.\mathrm{R}^{\prime}=\mathrm{H}\right]$ complexes of the investigated here at the mentioned level of theory.

the value of the $\mathrm{M} \leftarrow \mathrm{P}$ bond length also increased marginally (see Figure $1-3$ and Table 1 ).
Eventually, the minimum values of $\mathrm{M} \leftarrow \mathrm{C}$ and $\mathrm{M} \leftarrow \mathrm{S}$ bond lengths in $\left[\mathrm{Tgt} \rightarrow \mathrm{MNHC}(\mathrm{R})\left(\mathrm{R}^{\prime}\right)\right]$ complexes are observed in 


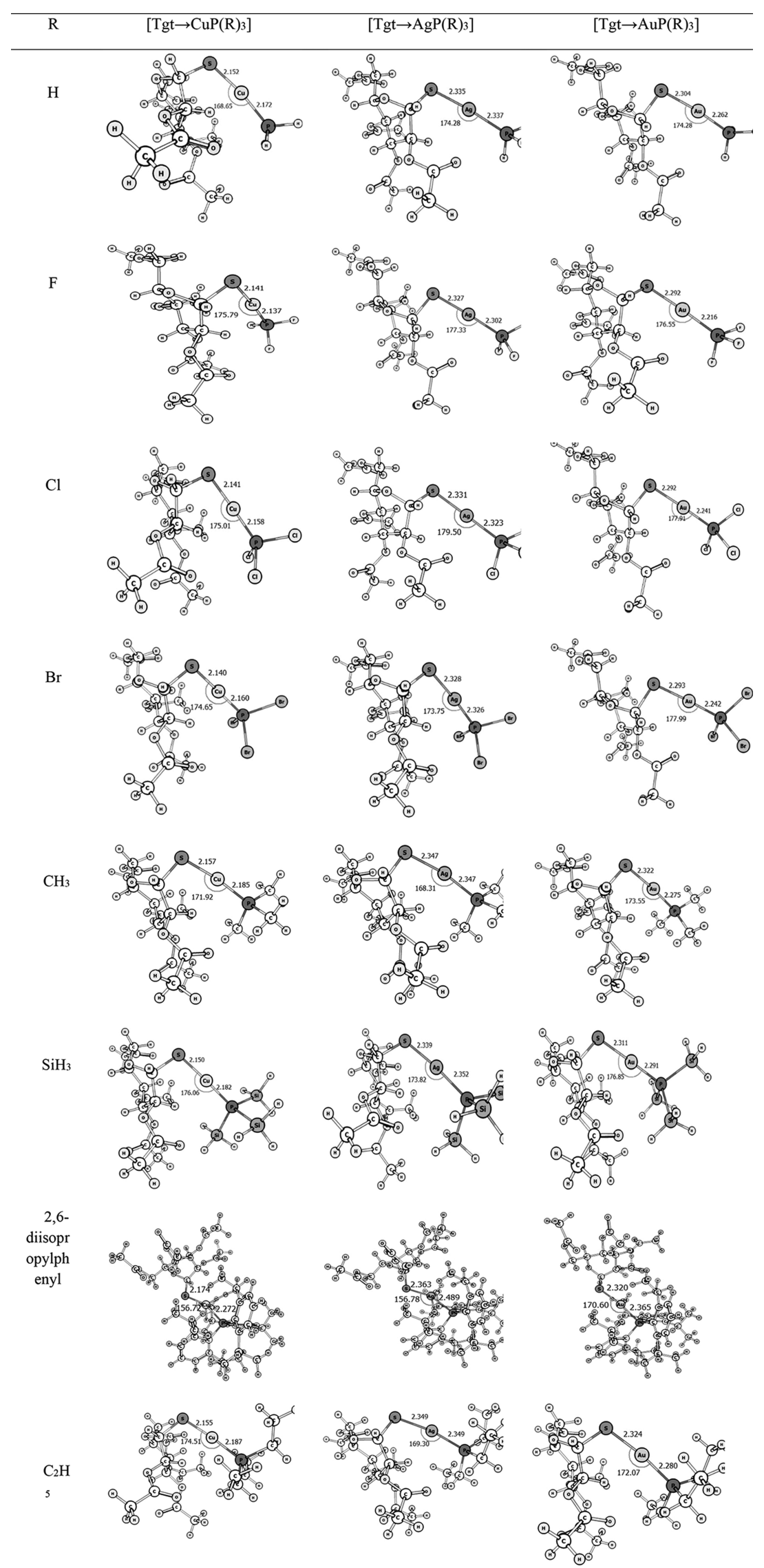

Figure 2. Optimized structures of [Tgt $\left.\rightarrow \mathrm{MP}(\mathrm{R})_{3}\right]\left[\mathrm{M}=\mathrm{Cu}(\mathrm{I}), \mathrm{Ag}(\mathrm{I}), \mathrm{Au}(\mathrm{I}) ; \mathrm{R}=\mathrm{F}, \mathrm{Cl}, \mathrm{Br}, \mathrm{H}, \mathrm{CH}_{3}, \mathrm{C}_{2} \mathrm{H}_{5}, \mathrm{SiH}_{3}\right.$, 2,6-diisopropylphenyl] complexes of the investigated here at the mentioned level of theory. 

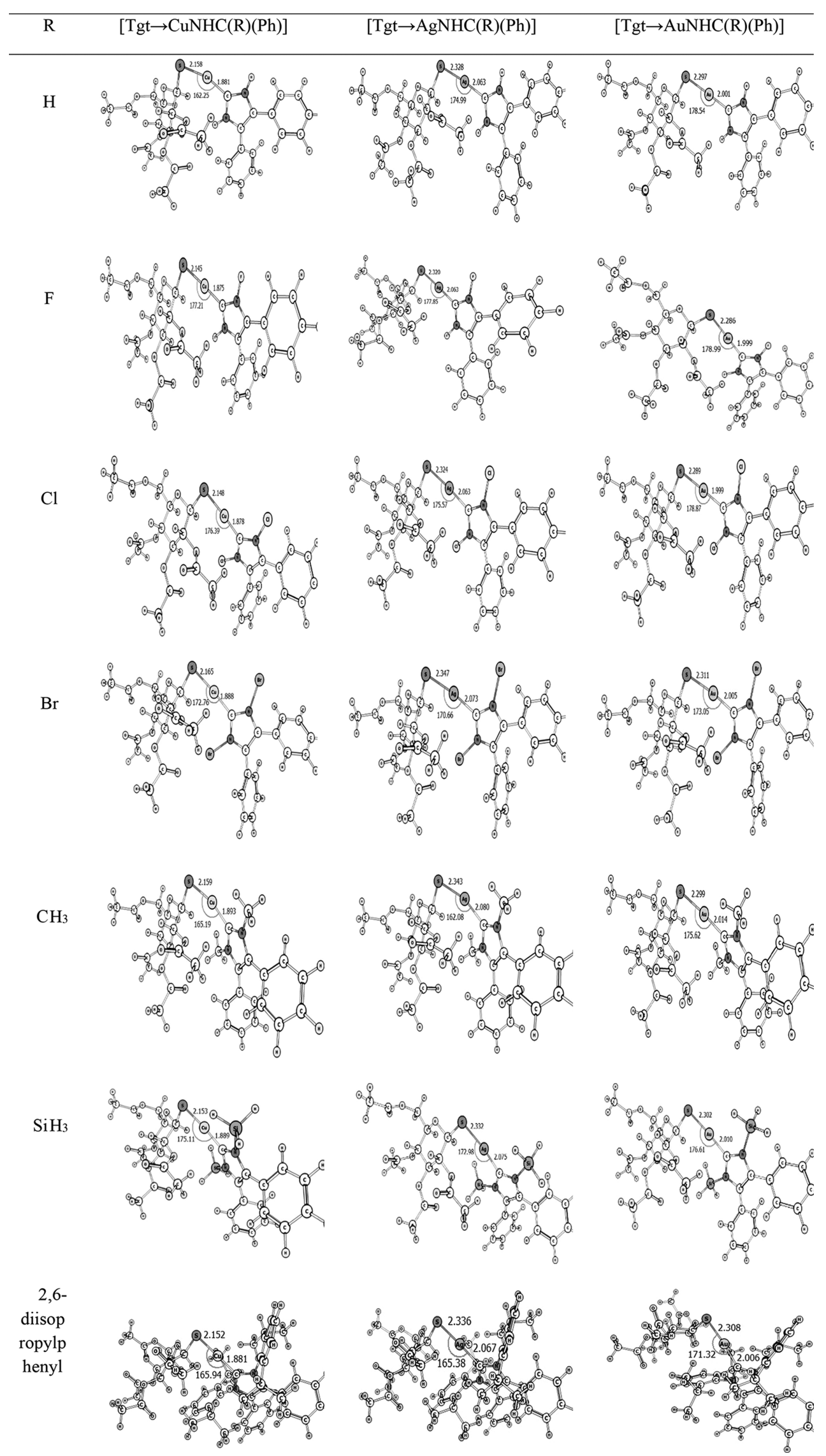

Figure 3. Optimized structures of $[\mathrm{Tgt} \rightarrow \operatorname{MNHC}(\mathrm{R})(\mathrm{Ph})]\left[\mathrm{M}=\mathrm{Cu}(\mathrm{I}), \mathrm{Ag}(\mathrm{I}), \mathrm{Au}(\mathrm{I}) ; \mathrm{R}=\mathrm{F}, \mathrm{Cl}, \mathrm{Br}, \mathrm{H}, \mathrm{CH}_{3}, \mathrm{SiH}_{3}\right.$, 2,6-diisopropylphenyl; $\left.\mathrm{R}^{\prime}=\mathrm{Ph}\right]$ complexes of the investigated here at the mentioned level of theory. 
Table 2. Corrected $\Delta E_{\text {int }}\left(\mathrm{kcal} \mathrm{mol}^{-1}\right)$ Considering the BSSE Values for $\left[\right.$ Tgt $\rightarrow$ M-NHC $\left.(\mathbf{R})\left(\mathbf{R}^{\prime}\right)\right]$ and $\left[\mathrm{Tgt} \rightarrow \mathbf{M}\left\{\mathbf{P}(\mathbf{R})_{3}\right\}\right][M=$ $\mathrm{Cu}(\mathrm{I}), \mathrm{Ag}(\mathrm{I}), \mathrm{Au}(\mathrm{I}) ; \mathrm{R}=\mathrm{F}, \mathrm{Cl}, \mathrm{Br}, \mathrm{H}, \mathrm{CH}_{3}, \mathrm{C}_{2} \mathrm{H}_{5}, \mathrm{SiH}_{3}, 2,6-$ Diisopropylphenyl; $\mathrm{R}^{\prime}=\mathrm{H}$ and Ph] at the PBE-D3/def2-TZVP Level of Theory

\begin{tabular}{|c|c|c|c|c|}
\hline$\Delta E_{\text {int }}$ & & {$[\mathrm{Tgt} \rightarrow \mathrm{CuNHC}(\mathrm{R})(\mathrm{H})]$} & {$\left[\mathrm{Tgt} \rightarrow \mathrm{CuP}(\mathrm{R})_{3}\right]$} & {$[\mathrm{Tgt} \rightarrow \mathrm{CuNHC}(\mathrm{R})(\mathrm{Ph})]$} \\
\hline $\mathrm{R}$ & M & & $\Delta E_{\text {int }}\left(\mathrm{kcal} \mathrm{mol}^{-1}\right)$ & \\
\hline \multirow[t]{3}{*}{$\mathrm{H}$} & $\mathrm{Cu}$ & -156.89 & -162.81 & -150.11 \\
\hline & $\mathrm{Ag}$ & -145.66 & -154.45 & -136.05 \\
\hline & $\mathrm{Au}$ & -161.74 & -173.07 & -152.30 \\
\hline \multirow[t]{3}{*}{$\mathrm{F}$} & $\mathrm{Cu}$ & -157.34 & -179.49 & -150.27 \\
\hline & $\mathrm{Ag}$ & -149.05 & -170.88 & -136.05 \\
\hline & $\mathrm{Au}$ & -166.37 & -192.99 & -158.97 \\
\hline \multirow[t]{3}{*}{$\mathrm{Cl}$} & $\mathrm{Cu}$ & -155.84 & -171.31 & -147.79 \\
\hline & $\mathrm{Ag}$ & -148.69 & -161.94 & -137.03 \\
\hline & $\mathrm{Au}$ & -161.57 & -181.02 & -155.15 \\
\hline \multirow[t]{3}{*}{$\mathrm{Br}$} & $\mathrm{Cu}$ & -156.20 & -169.50 & -148.85 \\
\hline & $\mathrm{Ag}$ & -147.74 & -157.00 & -138.79 \\
\hline & $\mathrm{Au}$ & -159.63 & -177.78 & -156.28 \\
\hline \multirow[t]{3}{*}{$\mathrm{CH}_{3}$} & $\mathrm{Cu}$ & -153.68 & -151.27 & -148.35 \\
\hline & $\mathrm{Ag}$ & -145.03 & -140.36 & -137.93 \\
\hline & $\mathrm{Au}$ & -159.07 & -154.07 & -150.39 \\
\hline \multirow[t]{3}{*}{$\mathrm{SiH}_{3}$} & $\mathrm{Cu}$ & -155.92 & -153.35 & -145.74 \\
\hline & $\mathrm{Ag}$ & -144.89 & -142.61 & -135.08 \\
\hline & $\mathrm{Au}$ & -161.70 & -158.65 & -151.16 \\
\hline \multirow[t]{3}{*}{ 2,6-diisopropyl phenyl } & $\mathrm{Cu}$ & -148.03 & -133.06 & -145.13 \\
\hline & $\mathrm{Ag}$ & -137.22 & -124.87 & -134.06 \\
\hline & $\mathrm{Au}$ & -154.13 & -138.05 & -149.00 \\
\hline \multirow[t]{3}{*}{$\mathrm{C}_{2} \mathrm{H}_{5}$} & $\mathrm{Cu}$ & & -148.55 & \\
\hline & $\mathrm{Ag}$ & & -136.38 & \\
\hline & $\mathrm{Au}$ & & -151.45 & \\
\hline
\end{tabular}

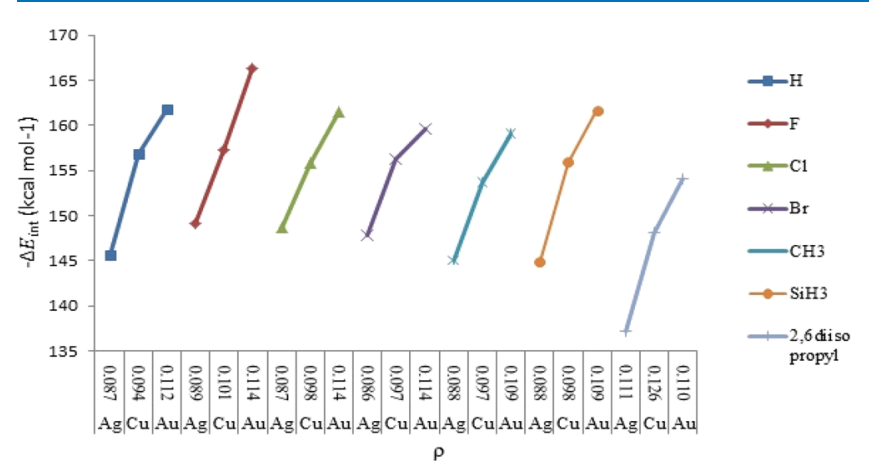

Figure 4. Calculated $\Delta E_{\text {int }}$ vs electron density $(\rho)$ for the $\mathrm{M}-\mathrm{S}$ bond of $[\mathrm{Tgt} \rightarrow \mathrm{MNHC}(\mathrm{R})(\mathrm{H})][\mathrm{M}=\mathrm{Cu}(\mathrm{I}), \mathrm{Ag}(\mathrm{I}), \mathrm{Au}(\mathrm{I}) ; \mathrm{R}=\mathrm{F}, \mathrm{Cl}, \mathrm{Br}, \mathrm{H}$, $\mathrm{CH}_{3}, \mathrm{SiH}_{3}$, 2,6-diisopropylphenyl; $\mathrm{R}^{\prime}=\mathrm{H}$ ].

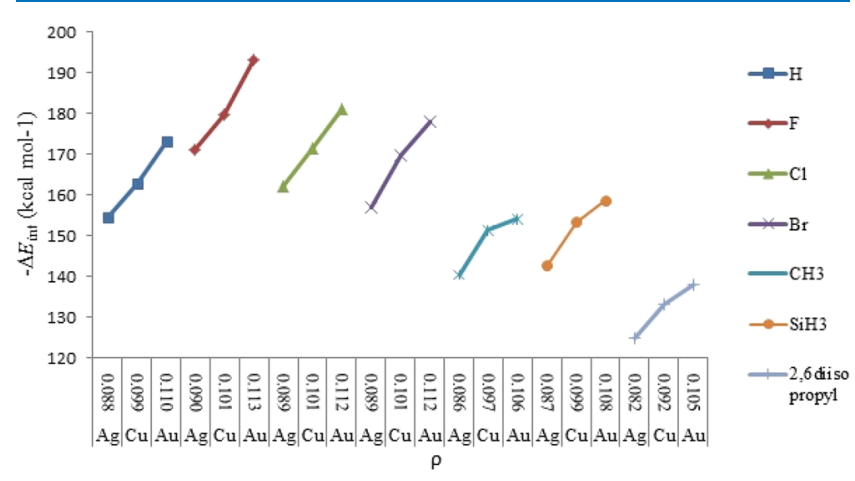

Figure 5. Calculated $\Delta E_{\text {int }}$ vs electron density $(\rho)$ for the $\mathrm{M}-\mathrm{S}$ bond of $\left[\mathrm{Tgt} \rightarrow \mathrm{MPR}_{3}\right]\left[\mathrm{M}=\mathrm{Cu}(\mathrm{I}), \mathrm{Ag}(\mathrm{I}), \mathrm{Au}(\mathrm{I}) ; \mathrm{R}=\mathrm{F}, \mathrm{Cl}, \mathrm{Br}, \mathrm{H}, \mathrm{CH}_{3}, \mathrm{SiH}_{3}\right.$, 2,6-diisopropylphenyl].
$[$ Tgt $\rightarrow \mathrm{CuNHC}(\mathrm{F})(\mathrm{H})]$, which are approximately 1.87 and $2.14 \AA$, respectively.

In addition, we can see the smallest $\mathrm{M} \leftarrow \mathrm{P}$ bond length in $\left[\mathrm{Tgt} \rightarrow \mathrm{MPR}_{3}\right]$ complexes in the $\left[\mathrm{Tgt} \rightarrow \mathrm{CuPF}_{3}\right]$ complex, which is approximately $2.14 \AA$.

Moreover, in $\left[\mathrm{Tgt} \rightarrow \mathrm{CuP}(\mathrm{X})_{3}\right](\mathrm{X}=\mathrm{F}, \mathrm{Cl}, \mathrm{Br})$ complexes, the minimum value for $\mathrm{M} \leftarrow \mathrm{S}$ bond length in the complexes is shown, which is approximately $2.14 \AA$ (see Figures $1-3$ and Table S1).

Results have shown that the modification of the $\mathrm{R}$ in $[\mathrm{Tgt} \rightarrow$ $\left.\mathrm{MPR}_{3}\right]$ and $\mathrm{R}$ and $\mathrm{R}^{\prime}$ in $\left[\mathrm{Tgt} \rightarrow \mathrm{MNHC}(\mathrm{R})\left(\mathrm{R}^{\prime}\right)\right]$ complexes has an insignificant effect on the $\mathrm{M} \leftarrow \mathrm{C}, \mathrm{M} \leftarrow \mathrm{P}$, and $\mathrm{M} \leftarrow \mathrm{S}$ bond lengths values (see Figures $1-3$ and Table S1).

3.2. Interaction Energy. Uncorrected interaction energies $\left(\Delta E_{\text {int }}\right)$ between $\left[\mathrm{MNHC}(\mathrm{R})\left(\mathrm{R}^{\prime}\right)\right]^{+}$and $\left[\mathrm{MPR}_{3}\right]^{+}$with $[\mathrm{Tgt}]^{-}$fragments in the optimized structure of $[\mathrm{Tgt} \rightarrow$ $\left.\operatorname{MNHC}(\mathrm{R})\left(\mathrm{R}^{\prime}\right)\right]$ and $\left[\mathrm{Tgt} \rightarrow \mathrm{MPR}_{3}\right]\{\mathrm{M}=\mathrm{Cu}(\mathrm{I}), \operatorname{Ag}(\mathrm{I})$, $\mathrm{Au}(\mathrm{I}) ; \mathrm{R}=\mathrm{F}, \mathrm{Cl}, \mathrm{Br}, \mathrm{H}, \mathrm{CH}_{3}, \mathrm{C}_{2} \mathrm{H}_{5}, \mathrm{SiH}_{3}$, 2,6-diisopropylphenyl; $\mathrm{R}^{\prime}=\mathrm{H}$ and $\mathrm{Ph}$ [as these substitutes are given on two noncarbenic carbon atoms $\left(\mathrm{C}_{4}\right.$ and $\left.\mathrm{C}_{5}\right)$ in the heterocycle]\} were calculated at the PBE-D3/def2-TZVP level of theory. The interaction energy was measured according to the following equation

$$
\Delta E_{\text {int }}=E_{\mathrm{AB}}-\left(E_{\mathrm{AB}}^{\mathrm{A}}+E_{\mathrm{AB}}^{\mathrm{B}}\right)
$$

From this perspective, it should be said that $E_{\mathrm{AB}}$ represents the electrical energy of $\left[\mathrm{Tgt} \rightarrow \mathrm{MNHC}(\mathrm{R})\left(\mathrm{R}^{\prime}\right)\right]$ and $[\mathrm{Tgt} \rightarrow$ $\left.\mathrm{MPR}_{3}\right]$ complexes and $E_{\mathrm{AB}}^{\mathrm{A}}$ and $E_{\mathrm{AB}}^{\mathrm{B}}$ represent the electrical energies of the two interactive fragments in the optimized structure of the complexes. The uncorrected $\Delta E_{\text {int }}$ for all complexes is shown in Table S5. 


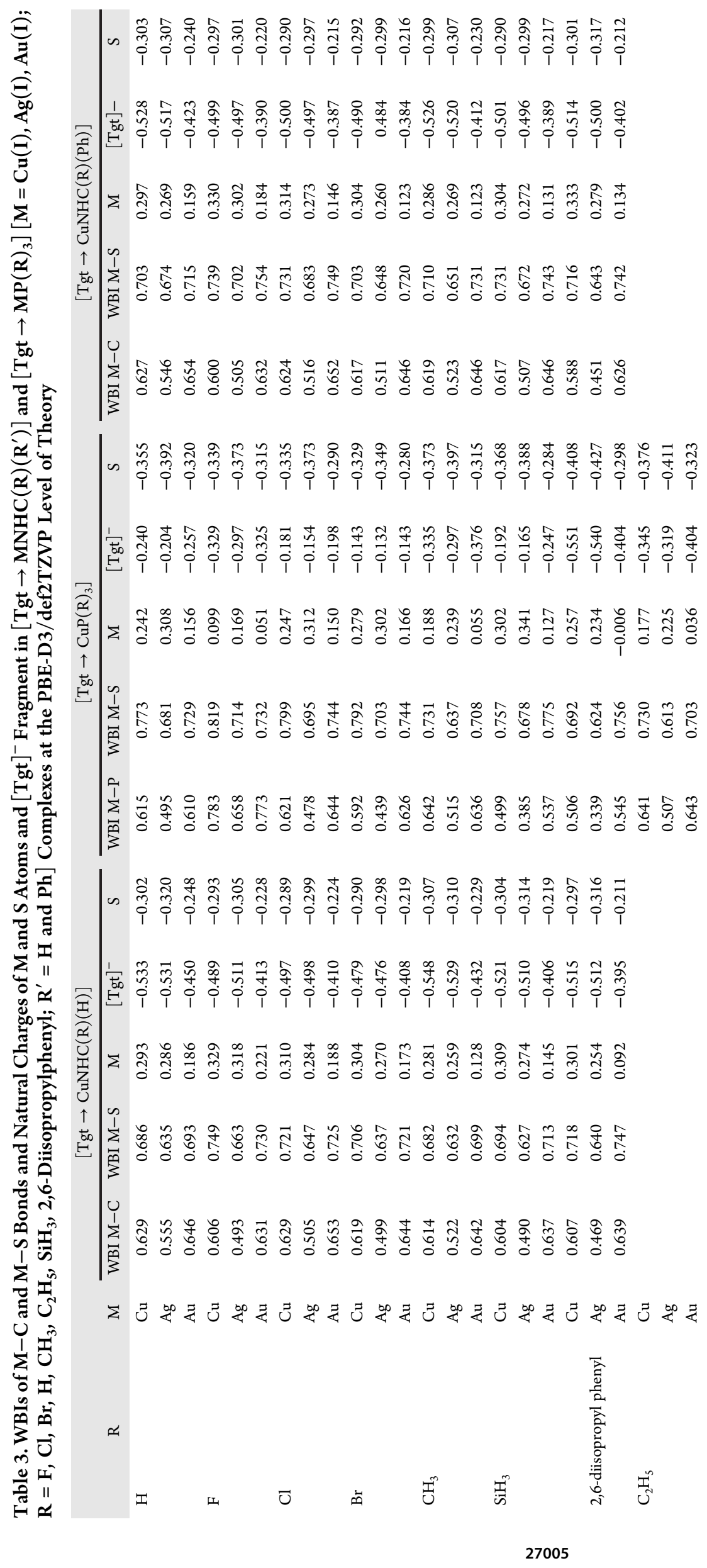


Table 4. EDA $^{a}$ Analysis (BP86-D3/TZ2P(ZORA)//PBE-D3/def2-TZVP) of the $\left[\mathrm{Tgt} \rightarrow \operatorname{MNHC}(\mathrm{R})\left(\mathrm{R}^{\prime}\right)\right]$ and $[\mathrm{Tgt} \rightarrow$ $\mathrm{MP}(\mathrm{R})_{3}$ ] Complexes $\left[\mathrm{M}=\mathrm{Cu}(\mathrm{I}) ; \mathrm{R}=\mathrm{F}, \mathrm{Cl}, \mathrm{Br}, \mathrm{H}, \mathrm{CH}_{3}, \mathrm{C}_{2} \mathrm{H}_{5}, \mathrm{SiH}_{3}, 2\right.$,6-Diisopropylphenyl; $\mathrm{R}^{\prime}=\mathrm{H}$ and $\mathrm{Ph}$ ]

\begin{tabular}{|c|c|c|c|c|}
\hline $\mathrm{R}$ & & {$[\mathrm{Tgt} \rightarrow \mathrm{CuNHC}(\mathrm{R})(\mathrm{H})]$} & {$\left[\mathrm{Tgt} \rightarrow \mathrm{CuP}(\mathrm{R})_{3}\right]$} & {$[$ Tgt $\rightarrow \operatorname{CuNHC}(\mathrm{R})(\mathrm{Ph})]$} \\
\hline \multirow[t]{8}{*}{$\mathrm{H}$} & $\Delta E_{\text {int }}$ & -161.86 & -168.07 & -155.73 \\
\hline & $\Delta E_{\text {pauli }}$ & 105.91 & 104.27 & 106.93 \\
\hline & $\Delta E_{\text {elast }}$ & $-188.69(70.50 \%)$ & $-190.64(70.0 \%)$ & $-180.96(68.90 \%)$ \\
\hline & $\Delta E_{\text {orb }}$ & $-69.5(26.00 \%)$ & $-73.47(27.0 \%)$ & $-69.76(26.56 \%)$ \\
\hline & $\Delta E_{\text {disper }}$ & $-9.58(3.60 \%)$ & $-8.22(3.1 \%)$ & $-11.94(2.51)$ \\
\hline & $\Delta E_{\mathrm{orb}, \sigma}$ & -34.52 & -43.14 & -35.00 \\
\hline & $\Delta E_{\mathrm{orb}, \pi}$ & -23.40 & -15.72 & -22.12 \\
\hline & $\Delta E_{\text {orb,rest }}$ & -10.43 & -10.50 & -11.50 \\
\hline \multirow[t]{8}{*}{$\mathrm{F}$} & $\Delta E_{\text {int }}$ & -162.61 & -186.72 & -155.63 \\
\hline & $\Delta E_{\text {pauli }}$ & 95.31 & 105.00 & 96.68 \\
\hline & $\Delta E_{\text {elast }}$ & $-181.21(70.30 \%)$ & $-199.01(68.3 \%)$ & $-174.35(69.10 \%)$ \\
\hline & $\Delta E_{\text {orb }}$ & $-70.02(27.20 \%)$ & $-83.20(28.6 \%)$ & $-69.90(27.70 \%)$ \\
\hline & $\Delta E_{\text {disper }}$ & $-6.69(2.60 \%)$ & $-9.51(3.3 \%)$ & $-8.07(3.20 \%)$ \\
\hline & $\Delta E_{\mathrm{orb}, \sigma}$ & -37.20 & -47.92 & -36.40 \\
\hline & $\Delta E_{\mathrm{orb}, \pi}$ & -24.43 & -23.00 & -24.25 \\
\hline & $\Delta E_{\text {orb,rest }}$ & -9.40 & -12.14 & -10.25 \\
\hline \multirow[t]{8}{*}{$\mathrm{Cl}$} & $\Delta E_{\text {int }}$ & -160.32 & -177.17 & -153.55 \\
\hline & $\Delta E_{\text {pauli }}$ & 99.46 & 106.68 & 98.61 \\
\hline & $\Delta E_{\text {elast }}$ & $-181.87(70.00 \%)$ & $-192.37(67.8 \%)$ & $-173.02(68.62 \%)$ \\
\hline & $\Delta E_{\text {orb }}$ & $-69.10(26.60 \%)$ & $-81.46(28.7 \%)$ & $-69.19(27.44 \%)$ \\
\hline & $\Delta E_{\text {disper }}$ & $-8.81(3.40 \%)$ & $-10.02(3.6 \%)$ & $-9.95(3.95 \%)$ \\
\hline & $\Delta E_{\mathrm{orb}, \sigma}$ & -35.61 & -47.09 & -34.65 \\
\hline & $\Delta E_{\mathrm{orb}, \pi}$ & -22.55 & -21.15 & -23.18 \\
\hline & $\Delta E_{\text {orb,rest }}$ & -9.92 & -11.35 & -8.16 \\
\hline \multirow[t]{8}{*}{$\mathrm{Br}$} & $\Delta E_{\text {int }}$ & -161.51 & -175.32 & -155.55 \\
\hline & $\Delta E_{\text {pauli }}$ & 104.57 & 107.81 & 103.22 \\
\hline & $\Delta E_{\text {elast }}$ & $-184.49(69.4 \%)$ & $-190.63(67.40 \%)$ & $-175.86(67.96 \%)$ \\
\hline & $\Delta E_{\text {orb }}$ & $-71.85(27.0 \%)$ & $-81.55(28.80 \%)$ & $-71.34(27.57 \%)$ \\
\hline & $\Delta E_{\text {disper }}$ & $-9.73(3.70 \%)$ & $-10.96(3.90 \%)$ & $-11.56(4.47 \%)$ \\
\hline & $\Delta E_{\mathrm{orb}, \sigma}$ & -34.50 & -47.17 & -30.80 \\
\hline & $\Delta E_{\mathrm{orb}, \pi}$ & -26.16 & -17.59 & -25.19 \\
\hline & $\Delta E_{\text {orb,rest }}$ & -11.91 & -11.57 & -10.47 \\
\hline \multirow[t]{8}{*}{$\mathrm{CH}_{3}$} & $\Delta E_{\text {int }}$ & -157.72 & -154.84 & -154.42 \\
\hline & $\Delta E_{\text {pauli }}$ & 103.39 & 107.08 & 107.41 \\
\hline & $\Delta E_{\text {elast }}$ & $-185.41(71.00 \%)$ & $-182.54(69.7 \%)$ & $-177.48(67.79 \%)$ \\
\hline & $\Delta E_{\mathrm{orb}}$ & $-64.87(24.90 \%)$ & $-69.66(26.6 \%)$ & $-69.38(26.50 \%)$ \\
\hline & $\Delta E_{\text {disper }}$ & $-10.83(4.20 \%)$ & $-9.72(3.8 \%)$ & $-14.96(5.71 \%)$ \\
\hline & $\Delta E_{\mathrm{orb}, \sigma}$ & -32.76 & -41.04 & -34.94 \\
\hline & $\Delta E_{\mathrm{orb}, \pi}$ & -19.71 & -13.73 & -22.12 \\
\hline & $\Delta E_{\text {orb,rest }}$ & -11.74 & -10.61 & -12.74 \\
\hline \multirow[t]{8}{*}{$\mathrm{SiH}_{3}$} & $\Delta E_{\text {int }}$ & -160.25 & -156.51 & -151.68 \\
\hline & $\Delta E_{\text {pauli }}$ & 99.97 & 104.82 & 102.48 \\
\hline & $\Delta E_{\text {elast }}$ & $-181.85(69.90 \%)$ & $-180.74(69.0 \%)$ & $-172.14(67.73 \%)$ \\
\hline & $\Delta E_{\mathrm{orb}}$ & $-67.44(26.00 \%)$ & $-71.24(27.20 \%)$ & $-69.49(27.34 \%)$ \\
\hline & $\Delta E_{\text {disper }}$ & $-10.92(4.20 \%)$ & $-9.36(3.60 \%)$ & $-12.53(4.93 \%)$ \\
\hline & $\Delta E_{\mathrm{orb}, \sigma}$ & -33.74 & -42.22 & -35.32 \\
\hline & $\Delta E_{\mathrm{orb}, \pi}$ & -19.99 & -13.92 & -22.22 \\
\hline & $\Delta E_{\text {orb,rest }}$ & -11.21 & -10.38 & -10.11 \\
\hline \multirow[t]{11}{*}{ 2,6-diisopropyl phenyl } & $\Delta E_{\text {int }}$ & -151.41 & -139.97 & -152.27 \\
\hline & $\Delta E_{\text {pauli }}$ & 107.77 & 116.02 & 111.43 \\
\hline & $\Delta E_{\text {elast }}$ & $-174.03(67.20 \%)$ & $-165.89(64.80 \%)$ & $-172.85(65.55 \%)$ \\
\hline & $\Delta E_{\text {orb }}$ & $-67.70(26.20 \%)$ & $-69.20(27.03 \%)$ & $-68.80(26.09 \%)$ \\
\hline & $\Delta E$ disper & $-17.45(6.80 \%)$ & $-20.90(8.16 \%)$ & $-22.06(8.37 \%)$ \\
\hline & $\Delta E_{\mathrm{orb}, \sigma}$ & -33.55 & -40.49 & -33.04 \\
\hline & $\Delta E_{\mathrm{orb}, \pi}$ & -21.62 & -12.48 & -22.31 \\
\hline & $\Delta E_{\text {orb,rest }}$ & -13.63 & -14.17 & -14.16 \\
\hline & $\Delta E_{\text {int }}$ & & -153.03 & \\
\hline & $\Delta E_{\text {pauli }}$ & & 108.76 & \\
\hline & $\Delta E_{\text {elast }}$ & & $-179.56(68.4 \%)$ & \\
\hline $\mathrm{C}_{2} \mathrm{H}_{5}$ & $\Delta E_{\text {orb }}$ & & $-68.75(26.2 \%)$ & \\
\hline
\end{tabular}


Table 4. continued

\begin{tabular}{|c|c|c|c|}
\hline $\mathrm{R}$ & {$[$ Tgt $\rightarrow \operatorname{CuNHC}(\mathrm{R})(\mathrm{H})]$} & {$\left[\mathrm{Tgt} \rightarrow \mathrm{CuP}(\mathrm{R})_{3}\right]$} & {$[\mathrm{Tgt} \rightarrow \mathrm{CuNHC}(\mathrm{R})(\mathrm{Ph})]$} \\
\hline & $\Delta E_{\text {disper }}$ & $-14.39(5.5 \%)$ & \\
\hline & $\Delta E_{\mathrm{orb}, \sigma}$ & -40.60 & \\
\hline & $\Delta E_{\mathrm{orb}, \pi}$ & -13.34 & \\
\hline & $\Delta$ Eorb,rest & -10.52 & \\
\hline
\end{tabular}

Furthermore, the objective was to gain correct results on the basis of the fixed superposition error (BSSE) and to use the counterpoise method, as proposed by Boys and Bernardi (see Tables S2-S4). ${ }^{33}$ In this sense, to minimize the BSSE, this procedure can determine a correction term using the same basis set for the molecule and its subunits. The theoretically corrected and uncorrected $\Delta E_{\text {int }}$ for all of the complexes analyzed is given in Tables 2 and S5, respectively.

When we have the same $\mathrm{M}$ atom and $\mathrm{R}$ substituent $(\mathrm{R}=\mathrm{F}, \mathrm{Cl}$, $\mathrm{Br}, \mathrm{H}, \mathrm{CH}_{3}, \mathrm{C}_{2} \mathrm{H}_{5}, \mathrm{SiH}_{3}, 2$,6-diisopropylphenyl) in [Tgt $\rightarrow$ $\left.\operatorname{MNHC}(\mathrm{R})\left(\mathrm{R}^{\prime}\right)\right]$ complexes and when the $\mathrm{R}^{\prime}$ from $\mathrm{H}$ is changed in to $\mathrm{Ph}$ for noncarbon atoms $\left(\mathrm{C}_{4}\right.$ and $\left.\mathrm{C}_{5}\right)$ in the heterocycle, we also observed a decrease in the value of $\Delta E_{\text {int. }}$. In this sense, in the case of $\left[\mathrm{Tgt} \rightarrow \mathrm{CuNHC}(\mathrm{H})\left(\mathrm{R}^{\prime}\right)\right], \Delta E_{\text {int }}$ values in the presence of $\mathrm{R}^{\prime}=\mathrm{H}$ and $\mathrm{Ph}$ are about 156.9 and $150.1 \mathrm{kcal} \mathrm{mol}^{-1}$, respectively.

In addition, the $\Delta E_{\text {int }}$ values of metal-drug $(\mathrm{M} \leftarrow S)$ bond in $\left[\mathrm{Tgt} \rightarrow \mathrm{MNHC}(\mathrm{R})\left(\mathrm{R}^{\prime}\right)\right]$ and $\left[\mathrm{Tgt} \rightarrow \mathrm{MPR}_{3}\right]$ complexes are significant and support the well-known $\mathrm{V}$-shape pattern for the transition metals of the first, second, and third rows as described in the following order: $\mathrm{Ag}(\mathrm{I})<\mathrm{Cu}(\mathrm{I})<\mathrm{Au}(\mathrm{I})$ (see Table 2).

In addition, the same findings concerning the bond interaction of $\mathrm{NHC}(\mathrm{R})$ with Group 11 of the transition-metal ions are identified with our group and also with the Frenking group. ${ }^{34,35}$ Findings demonstrate that the $\mathrm{Ag}(\mathrm{I})$ complexes have the smallest and $\mathrm{Au}(\mathrm{I})$ complexes have the highest levels of metal-drug interaction strength. As a result, relative to other complexes studied here, drug releases tend to be best promoted in $\mathrm{Ag}(\mathrm{I})$ complexes.

Moreover, considering the same $\mathrm{M}$ atom and changing the $\mathrm{L}$ ligand from $\mathrm{NHC}(\mathrm{R})\left(\mathrm{R}^{\prime}\right)$ to $\mathrm{PR}_{3}$ for electron-withdrawing substituents, that is, $\mathrm{F}, \mathrm{Cl}, \mathrm{Br}$, and $\mathrm{H}$, the strength of $\mathrm{M} \leftarrow \mathrm{S}$ bond in $[\mathrm{Tgt} \rightarrow \mathrm{ML}]$ was increased. In this respect, in the case of [Tgt $\rightarrow \mathrm{CuL}], \Delta E_{\text {int }}$ values in the presence of $\mathrm{NHC}(\mathrm{H})(\mathrm{H} / \mathrm{Ph})$ are approximately 156.9 and $150.1 \mathrm{kcal} \mathrm{mol}^{-1}$ and by changing the $\mathrm{L}$ ligand group to $\mathrm{PH}_{3}, \Delta E_{\text {int }}$ is approximately $162.8 \mathrm{kcal} \mathrm{mol}^{-1}$ (see Table 2).

Drug releases appear to be more facilitated in the presence of $\mathrm{NHC}(\mathrm{R})(\mathrm{Ph})$ ligands than other $\mathrm{PR}_{3}$ ligands studied here. In addition, as mentioned above, the $\Delta E_{\text {int }}$ value of metal-drug $(M$ $\leftarrow \mathrm{S})$ bond in $\left[\mathrm{Tgt} \rightarrow \operatorname{MNHC}(\mathrm{R})\left(\mathrm{R}^{\prime}\right)\right]$, in the presence of $\mathrm{R}^{\prime}=$ $\mathrm{H}$, is larger than that of $\mathrm{R}^{\prime}=\mathrm{Ph}$.

In various complexes, the effects of $\mathrm{R}$ substituted on $\mathrm{NHC}(\mathrm{R})\left(\mathrm{R}^{\prime}\right)$ and $\mathrm{PR}_{3}$ ligands are also regarded. Results demonstrate that $\Delta E_{\text {int }}$ values of the metal-drug $(\mathrm{M} \leftarrow \mathrm{S})$ bond in $\left[\mathrm{Tgt} \rightarrow \operatorname{MNHC}(\mathrm{R})\left(\mathrm{R}^{\prime}\right)\right]$ and $\left[\mathrm{Tgt} \rightarrow \mathrm{MPR}_{3}\right]$ complexes, in the presence of electron-withdrawing substituents $(\mathrm{R}=\mathrm{F}, \mathrm{Cl}, \mathrm{Br}$ ) are more significant than those for the electrondonating substituents $\left(\mathrm{R}=\mathrm{H}, \mathrm{CH}_{3}, \mathrm{C}_{2} \mathrm{H}_{5}, \mathrm{SiH}_{3}, 2\right.$, 6diisopropylphenyl) (see Table 2).

It is also noteworthy that, taking into account the same $M$ atom and $\mathrm{R}$ substituent, the differences between $\Delta E_{\text {int }}$ of the metal-drug $(\mathrm{M} \leftarrow S)$ bond in the presence of electron-donating and electron-withdrawing substituents in [Tgt $\left.\rightarrow \mathrm{MPR}_{3}\right]$ complexes are more substantial than those of the $[\mathrm{Tgt} \rightarrow$ $\operatorname{MNHC}(\mathrm{R})\left(\mathrm{R}^{\prime}\right)$ ] complexes. In this regard, it must be emphasized that the difference between $\Delta E_{\text {int }}$ of the metaldrug $(\mathrm{M} \leftarrow \mathrm{S})$ bond in $\left[\mathrm{Tgt} \rightarrow \mathrm{CuPR}_{3}\right.$ ] complexes with $\mathrm{R}=\mathrm{H}$ and $\mathrm{F}$ is approximately $17 \mathrm{kcal} \mathrm{mol}^{-1}$ and that for [Tgt $\rightarrow$ $\mathrm{CuNHC}(\mathrm{R})(\mathrm{H} / \mathrm{Ph})]$ complexes is approximately $1 \mathrm{kcal} \mathrm{mol}^{-1}$ (see Table 2).

Finally, it can be inferred that among the [Tgt $\rightarrow$ $\left.\operatorname{AuMNHC}(\mathrm{R})\left(\mathrm{R}^{\prime}\right)\right]$ complexes studied here, [Tgt $\rightarrow$ AgNHC(2,6-diisopropylphenyl) $(\mathrm{Ph})]$ and $[\mathrm{Tgt} \rightarrow \operatorname{AuNHC}(\mathrm{F})(\mathrm{H})]$ have the smallest and largest amounts of interaction energies, respectively. On the other hand, in $\left[\mathrm{Tgt} \rightarrow \mathrm{MPR}_{3}\right]$ complexes, the $\left[\mathrm{Tgt} \rightarrow \operatorname{AgP}(2,6 \text {-diisopropylphenyl })_{3}\right]$ and $\left[\mathrm{Tgt} \rightarrow \mathrm{AuPF}_{3}\right]$ have the smallest and largest values of $\Delta E_{\text {int }}$ of the metal-drug $(\mathrm{M} \leftarrow \mathrm{S})$ bond, respectively.

The analysis of the associated findings shows that the highest quantity of $\Delta E_{\text {int }}$ in the complexes corresponds to the electronwithdrawing substitutions $\mathrm{F}$ and $\mathrm{Au}$ ions of metal and that the smallest quantity corresponds to the electron-donating substituents 2,6-diisopropylphenyl and Ag ions of metal (see Table 2).

Consequently, it can be inferred that in the presence of the same $\mathrm{M}$ metal ion and $\mathrm{R}=\mathrm{F}, \mathrm{Cl}, \mathrm{Br}$, and $\mathrm{H}$ substituents, the group 11 metals can generate stronger bonds with $[\mathrm{Tgt}]^{-}$drug in the form $\left[\mathrm{Tgt} \rightarrow \mathrm{MPR}_{3}\right]$ than $\left[\mathrm{Tgt} \rightarrow \operatorname{MNHC}(\mathrm{R})\left(\mathrm{R}^{\prime}\right)\right]$ complexes (see Table 2).

3.3. AIM Analysis. Bader's theory of atoms in molecules (AIM theory) was used to investigate the bond critical points (BCPs). In the present paper, we attempt to analyze the BCPs at $\mathrm{M} \leftarrow \mathrm{C}$ and $\mathrm{M} \leftarrow \mathrm{S}$ bonds in [Tgt $\rightarrow \mathrm{MNHC}(\mathrm{R})\left(\mathrm{R}^{\prime}\right)$ ] as well as $\mathrm{M} \leftarrow \mathrm{P}$ and $\mathrm{M} \leftarrow \mathrm{S}$ bonds in [Tgt $\left.\rightarrow \mathrm{MPR}_{3}\right][\mathrm{M}=\mathrm{Cu}(\mathrm{I}), \mathrm{Ag}(\mathrm{I})$, $\mathrm{Au}(\mathrm{I}) ; \mathrm{R}=\mathrm{F}, \mathrm{Cl}, \mathrm{Br}, \mathrm{H}, \mathrm{CH}_{3}, \mathrm{C}_{2} \mathrm{H}_{5}, \mathrm{SiH}_{3}$, 2,6-diisopropylphenyl; $\mathrm{R}^{\prime}=\mathrm{H}$ and $\mathrm{Ph}$ ] [as these substituents are given on two noncarbenic carbon atoms $\left(\mathrm{C}_{4}\right.$ and $\left.\mathrm{C}_{5}\right)$ in the heterocycle] complexes using AIM theory.

As can be seen in Tables S6-S8, the topological properties of the interactions have been calculated at the BCPs. The $\nabla^{2} \rho$ (laplacian of electron density) and $-G_{c} / V_{c}\left(G_{c}\right.$ is the kinetic energy and a positive quantity, $V_{\mathrm{c}}$ is the potential energy and a negative quantity) values have also been used to study the nature of the interaction. ${ }^{34}$ The effects of the substituents on the values of electron density $(\rho)$ of $\mathrm{M} \leftarrow \mathrm{C}$ and $\mathrm{M} \leftarrow \mathrm{S}$ bonds in [Tgt $\rightarrow$ $\operatorname{MNHC}(\mathrm{R})\left(\mathrm{R}^{\prime}\right)$ ] as well as $\mathrm{M} \leftarrow \mathrm{P}$ and $\mathrm{M} \leftarrow \mathrm{S}$ bonds in [Tgt $\rightarrow$ $\left.\mathrm{MPR}_{3}\right]$ are also investigated.

According to the acquired findings, it can be argued that the changing in the $\mathrm{R}$ substituents may not have a significant impact on the electron density values $(\rho)$ of on $\mathrm{M} \leftarrow \mathrm{C}, \mathrm{M} \leftarrow \mathrm{P}$ and $\mathrm{M}$ $\leftarrow \mathrm{S}$ bonds studied here (see Tables S6-S8).

Figures 4 and 5 represent a satisfactory correlation between the calculated $\Delta E_{\text {int }}$ and the corresponding electron density $(\rho)$ for the $\mathrm{M} \leftarrow \mathrm{S}$ bond in $\left[\mathrm{Tgt} \rightarrow \mathrm{MNHC}(\mathrm{R})\left(\mathrm{R}^{\prime}\right)\right]$ and $[$ Tgt $\rightarrow$ $\mathrm{MPR}_{3}$ ] complexes.

The aforementioned results, which are strongly in agreement with $\Delta E_{\text {int }}$ confirm the well-known $\mathrm{V}$-shaped trends of electron 
Table 5. EDA $^{a}$ Analysis (BP86-D3/TZ2P(ZORA)//PBE-D3/def2-TZVP) of the $\left[\mathrm{Tgt} \rightarrow \operatorname{MNHC}(\mathrm{R})\left(\mathrm{R}^{\prime}\right)\right]$ and $[\mathrm{Tgt} \rightarrow$ $\left.\mathrm{MP}(\mathrm{R})_{3}\right]$ Complexes $\left[\mathrm{M}=\mathrm{Ag}(\mathrm{I}) ; \mathrm{R}=\mathrm{F}, \mathrm{Cl}, \mathrm{Br}, \mathrm{H}, \mathrm{CH}_{3}, \mathrm{C}_{2} \mathrm{H}_{5}, \mathrm{SiH}_{3}, 2,6\right.$-Diisopropylphenyl; $\mathrm{R}^{\prime}=\mathrm{H}$ and $\mathrm{Ph}$ ]

\begin{tabular}{|c|c|c|c|c|}
\hline $\mathrm{R}$ & & {$[\mathrm{Tgt} \rightarrow \operatorname{AgNHC}(\mathrm{R})(\mathrm{H})]$} & {$\left[\mathrm{Tgt} \rightarrow \operatorname{AgP}(\mathrm{R})_{3}\right]$} & {$[\mathrm{Tgt} \rightarrow \operatorname{AgNHC}(\mathrm{R})(\mathrm{Ph})$} \\
\hline \multirow[t]{8}{*}{$\mathrm{H}$} & $\Delta E_{\text {int }}$ & -146.81 & -155.84 & -137.44 \\
\hline & $\Delta E_{\text {pauli }}$ & 105.98 & 104.16 & 107.08 \\
\hline & $\Delta E_{\text {elast }}$ & $-183.64(72.7 \%)$ & $-190.25(73.18 \%)$ & $-177.10(72.43 \%)$ \\
\hline & $\Delta E_{\text {orb }}$ & $-61.23(24.3 \%)$ & $-63.58(24.45 \%)$ & $-59.85(24.48 \%)$ \\
\hline & $\Delta E_{\text {disper }}$ & $-7.92(3.20 \%)$ & $-6.16(2.37 \%)$ & $-7.56(3.09 \%)$ \\
\hline & $\Delta E_{\mathrm{orb}, \sigma}$ & -30.02 & -39.83 & -32.68 \\
\hline & $\Delta E_{\mathrm{orb}, \pi}$ & -13.81 & -11.90 & -18.11 \\
\hline & $\Delta E_{\text {orb,rest }}$ & -10.98 & -10.44 & -9.51 \\
\hline \multirow[t]{8}{*}{$\mathrm{F}$} & $\Delta E_{\text {int }}$ & -150.28 & -173.46 & -140.64 \\
\hline & $\Delta E_{\text {pauli }}$ & 104.33 & 107.93 & 107.88 \\
\hline & $\Delta E_{\text {elast }}$ & $-187.23(73.60 \%)$ & $-202.06(71.80 \%)$ & $-179.26(72.13 \%)$ \\
\hline & $\Delta E_{\text {orb }}$ & $-59.54(23.40 \%)$ & $-72.43(25.80 \%)$ & $-61.78(24.86 \%)$ \\
\hline & $\Delta E_{\text {disper }}$ & $-7.85(3.10 \%)$ & $-6.90(2.50 \%)$ & $-7.48(3.01 \%)$ \\
\hline & $\Delta E_{\mathrm{orb}, \sigma}$ & -31.72 & -43.14 & -33.23 \\
\hline & $\Delta E_{\mathrm{orb}, \pi}$ & -18.83 & -18.30 & -19.55 \\
\hline & $\Delta E_{\text {orb,rest }}$ & -9.25 & -10.53 & -9.46 \\
\hline \multirow[t]{8}{*}{$\mathrm{Cl}$} & $\Delta E_{\text {int }}$ & -149.75 & -164.73 & -138.57 \\
\hline & $\Delta E_{\text {pauli }}$ & 108.57 & 107.38 & 108.93 \\
\hline & $\Delta E_{\text {elast }}$ & $-187.38(72.60 \%)$ & $-193.28(71.10 \%)$ & $-177.63(71.77 \%)$ \\
\hline & $\Delta E_{\text {orb }}$ & $-60.93(23.60)$ & $-71.61(26.40 \%)$ & $-60.92(24.61 \%)$ \\
\hline & $\Delta E_{\text {disper }}$ & $-10.01(3.90)$ & $-7.22(2.70 \%)$ & $-8.95(3.62 \%)$ \\
\hline & $\Delta E_{\mathrm{orb}, \sigma}$ & -30.93 & -43.11 & -32.42 \\
\hline & $\Delta E_{\mathrm{orb}, \pi}$ & -19.78 & -17.34 & -18.94 \\
\hline & $\Delta E_{\text {orb,rest }}$ & -9.85 & -10.39 & -9.84 \\
\hline \multirow[t]{8}{*}{$\mathrm{Br}$} & $\Delta E_{\text {int }}$ & -152.21 & -159.05 & -141.53 \\
\hline & $\Delta E_{\text {pauli }}$ & 114.77 & 114.47 & 112.71 \\
\hline & $\Delta E_{\text {elast }}$ & $-190.74(71.50 \%)$ & $-190.18(69.60 \%)$ & $-179.42(70.57 \%)$ \\
\hline & $\Delta E_{\text {orb }}$ & $-65.07(24.40 \%)$ & $-71.65(26.20 \%)$ & $-63.82(25.10 \%)$ \\
\hline & $\Delta E_{\text {disper }}$ & $-11.17(4.20 \%)$ & $-11.69(4.30 \%)$ & $-10.99(4.32 \%)$ \\
\hline & $\Delta E_{\mathrm{orb}, \sigma}$ & -30.23 & -42.69 & -30.80 \\
\hline & $\Delta E_{\mathrm{orb}, \pi}$ & -19.30 & -13.62 & -15.54 \\
\hline & $\Delta E_{\text {orb,rest }}$ & -11.82 & -11.12 & -12.06 \\
\hline \multirow[t]{8}{*}{$\mathrm{CH}_{3}$} & $\Delta E_{\text {int }}$ & -144.19 & -141.39 & -140.58 \\
\hline & $\Delta E_{\text {pauli }}$ & 106.73 & 111.76 & 114.52 \\
\hline & $\Delta E_{\text {elast }}$ & $-183.32(73.10 \%)$ & $-181.75(71.80 \%)$ & $-179.87(70.51 \%)$ \\
\hline & $\Delta E_{\text {orb }}$ & $-57.40(22.90 \%)$ & $-61.25(24.20 \%)$ & $-60.91(23.88 \%)$ \\
\hline & $\Delta E_{\text {disper }}$ & $-10.20(4.10 \%)$ & $-10.15(4.00 \%)$ & $-14.32(5.61 \%)$ \\
\hline & $\Delta E_{\mathrm{orb}, \sigma}$ & -30.11 & -37.25 & -31.88 \\
\hline & $\Delta E_{\mathrm{orb}, \pi}$ & -16.72 & -10.54 & -11.26 \\
\hline & $\Delta E_{\text {orb,rest }}$ & -10.26 & -13.48 & -12.07 \\
\hline \multirow[t]{8}{*}{$\mathrm{SiH}_{3}$} & $\Delta E_{\text {int }}$ & -146.24 & -142.86 & $-137.40-$ \\
\hline & $\Delta E_{\text {pauli }}$ & 108.28 & 110.40 & 111.03 \\
\hline & $\Delta E_{\text {elast }}$ & $-185.12(72.80 \%)$ & $-180.77(71.40 \%)$ & $-176.04(70.86 \%)$ \\
\hline & $\Delta E_{\mathrm{orb}}$ & $-59.13(23.30 \%)$ & $-61.25(24.90 \%)$ & $-61.07(24.58 \%)$ \\
\hline & $\Delta E_{\text {disper }}$ & $-10.27(4.10 \%)$ & $-9.49(3.80 \%)$ & $11.32-(4.56 \%)$ \\
\hline & $\Delta E_{\mathrm{orb}, \sigma}$ & -30.67 & -38.79 & -32.18 \\
\hline & $\Delta E_{\mathrm{orb}, \pi}$ & -15.73 & -10.76 & -11.60 \\
\hline & $\Delta E_{\text {orb,rest }}$ & -12.11 & -11.80 & -11.24 \\
\hline \multirow[t]{11}{*}{ 2,6-diisopropyl phenyl } & $\Delta E_{\text {int }}$ & -137.94 & -127.74 & -137.33 \\
\hline & $\Delta E_{\text {pauli }}$ & 115.84 & 115.99 & 118.18 \\
\hline & $\Delta E_{\text {elast }}$ & $-176.57(69.60 \%)$ & $-163.91(67.25 \%)$ & $-174.91(68.46 \%)$ \\
\hline & $\Delta E_{\text {orb }}$ & $-59.98(23.70 \%)$ & $-60.66(24.89 \%)$ & $-60.45(23.66 \%)$ \\
\hline & $\Delta E_{\text {disper }}$ & $-17.24(6.80 \%)$ & $-19.16(7.86 \%)$ & $-20.15(7.89 \%)$ \\
\hline & $\Delta E_{\mathrm{orb}, \sigma}$ & -30.72 & -35.75 & -30.32 \\
\hline & $\Delta E_{\mathrm{orb}, \pi}$ & -14.60 & -9.86 & -11.58 \\
\hline & $\Delta E_{\text {orb,rest }}$ & -12.72 & -14.86 & -13.15 \\
\hline & $\Delta E_{\text {int }}$ & & -138.91 & \\
\hline & $\Delta E_{\text {pauli }}$ & & 111.77 & \\
\hline & $\Delta E_{\text {elast }}$ & & $-178.90(71.37 \%)$ & \\
\hline $\mathrm{C}_{2} \mathrm{H}_{5}$ & $\Delta E_{\text {orb }}$ & & $-60.78(24.25 \%)$ & \\
\hline
\end{tabular}


Table 5. continued

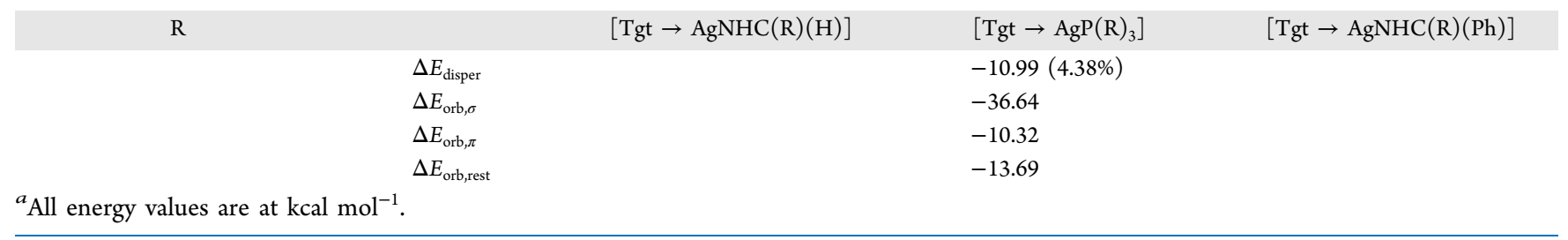

densities $(\rho)$ of $\mathrm{M} \leftarrow \mathrm{C}$ and $\mathrm{M} \leftarrow \mathrm{S}$ bonds in the [Tgt $\rightarrow$ $\left.\operatorname{MNHC}(\mathrm{R})\left(\mathrm{R}^{\prime}\right)\right]$ complex and the same is for $\mathrm{M} \leftarrow \mathrm{P}$ and $\mathrm{M} \leftarrow$ $\mathrm{S}$ bonds in $\left[\mathrm{Tgt} \rightarrow \mathrm{MPR}_{3}\right]\{\mathrm{M}=\mathrm{Cu}(\mathrm{I}), \mathrm{Ag}(\mathrm{I}), \mathrm{Au}(\mathrm{I}) ; \mathrm{R}=\mathrm{F}, \mathrm{Cl}$, $\mathrm{Br}, \mathrm{H}, \mathrm{CH}_{3}, \mathrm{C}_{2} \mathrm{H}_{5}, \mathrm{SiH}_{3}$, 2,6-diisopropylphenyl; $\mathrm{R}^{\prime}=\mathrm{H}$ and $\mathrm{Ph}$ [as these substituents are given on two noncarbenic carbon atoms $\left(\mathrm{C}_{4}\right.$ and $\left.\mathrm{C}_{5}\right)$ in the heterocycle] $\}$ complexes (see Tables S6-S8).

Subsequently, it has been observed that the smallest and largest electron density $(\rho)$ values in the presence of the same $\mathrm{R}$ substituent for $\mathrm{M} \leftarrow \mathrm{C}$ and $\mathrm{M} \leftarrow \mathrm{S}$ bonds in [Tgt $\rightarrow$ $\left.\operatorname{MNHC}(\mathrm{R})\left(\mathrm{R}^{\prime}\right)\right]$ as well as $\mathrm{M} \leftarrow \mathrm{P}$ and $\mathrm{M} \leftarrow \mathrm{S}$ bonds in [Tgt $\rightarrow$ $\left.\mathrm{MPR}_{3}\right]$ are associated with $\mathrm{Ag}$ and $\mathrm{Au}$ complexes, respectively (see Tables S6-S8).

The values of $\nabla^{2} \rho$ and $-G_{c} / V_{c}$ have also been used to analyze the nature of the interactions in the complexes. ${ }^{36,37}$ The results indicate that the $\mathrm{M} \leftarrow \mathrm{C}$ and $\mathrm{M} \leftarrow \mathrm{S}$ bonds in [Tgt $\rightarrow$ $\left.\operatorname{MNHC}(\mathrm{R})\left(\mathrm{R}^{\prime}\right)\right]$ as well as $\mathrm{M} \leftarrow \mathrm{P}$ and $\mathrm{M} \leftarrow \mathrm{S}$ bonds in [Tgt $\rightarrow$ $\left.\mathrm{MPR}_{3}\right]$ complexes are partly covalent $\left(\nabla^{2} \rho>0\right.$ and $-G_{\mathrm{c}} / V_{\mathrm{c}}<1$, see Tables S6-S8).

3.4. NBO Analysis. The natural bond orbital (NBO) analysis, which focuses on a technique for optimizing the transformation of a given wave function into a localized shape, corresponds to the Lewis structure of the chemist's one-center "lone pair" and two-center "bond" elements.

Assuming that the Lewis structures are bonding templates, the NBO approach was commonly accepted as understanding the bonding state. It is worth noting that the results obtained are very robust to the alteration of the basis set, which is the most significant advantage of the NBO analysis.

Based on NBO calculations at the PBE-D3/def2-TZVP level of theory, the nature of $\mathrm{M} \leftarrow \mathrm{C}, \mathrm{M} \leftarrow \mathrm{S}$, and $\mathrm{M} \leftarrow \mathrm{P}$ bonds in the complexes studied here is analyzed. The values of the partial charge on $\mathrm{S}$ and $\mathrm{M}$ atoms and also the total charge of [Tgt] fragment in $\left[\mathrm{Tgt} \rightarrow \mathrm{MNHC}(\mathrm{R})\left(\mathrm{R}^{\prime}\right)\right]$ as well as [Tgt $\rightarrow \mathrm{MPR}_{3}$ ] $\left\{\mathrm{M}=\mathrm{Cu}(\mathrm{I}), \mathrm{Ag}(\mathrm{I}), \mathrm{Au}(\mathrm{I}) ; \mathrm{R}=\mathrm{F}, \mathrm{Cl}, \mathrm{Br}, \mathrm{H}, \mathrm{CH}_{3}, \mathrm{C}_{2} \mathrm{H}_{5}, \mathrm{SiH}_{3}\right.$, 2,6-diisopropylphenyl; $\mathrm{R}^{\prime}=\mathrm{H}$ and $\mathrm{Ph}$ [as these substituents are given on two noncarbenic carbon atoms $\left(\mathrm{C}_{4}\right.$ and $\left.\mathrm{C}_{5}\right)$ in the heterocycle] \} complexes are investigated (see Table 3 ).

As can be seen in Table 3, acquired findings demonstrate that the $\mathrm{M}$ atoms carried positive charge except for Au in [Tgt $\rightarrow$ $\left.\operatorname{AuP}(2,6 \text {-diisopropylphenyl })_{3}\right]$ complex $\}$ and $S$ atom and [Tgt $]^{-}$ fragment carried the negative charges in the complexes.

Furthermore, in $\left[\mathrm{Tgt} \rightarrow \mathrm{MNHC}(\mathrm{R})\left(\mathrm{R}^{\prime}\right)\right]$ complexes, changing the $\mathrm{M}$ atom from $\mathrm{Cu}$ to $\mathrm{Au}$ in the presence of the same $R$ and $\mathrm{R}^{\prime}$ substituents leads to a reduction of the values of partial positive charge on the $\mathrm{M}$ atom; $\mathrm{Cu}(\mathrm{I})>\mathrm{Ag}(\mathrm{I})>\mathrm{Au}(\mathrm{I})$. Furthermore, there is no major impact on the amount of the partial charge on the $M$ atom by adjusting the substituent $R$. In addition, in the presence of the same $M$ metal center, changing the $\mathrm{R}$ substituent from $\mathrm{F}$ to $\mathrm{Br}$ leads to a slight decrease in the value of the partial positive charge on $\mathrm{M}$ atoms.

For example, the partial positive charge values for $\mathrm{Cu}$ atom in $[\mathrm{Tgt} \rightarrow \mathrm{CuNHC}(\mathrm{R})(\mathrm{H})]$ complexes concerning $\mathrm{R}=\mathrm{F}, \mathrm{Cl}$, and
$\mathrm{Br}$ are approximately $0.329 e, 0.310 e$, and $0.304 e$, respectively (see Table 3).

Changing the $\mathrm{M}$ metal center in $\left[\mathrm{Tgt} \rightarrow \mathrm{MPR}_{3}\right]$ complexes in the presence of the same $\mathrm{R}$ substituent results in increasing the partial positive charge values from $\mathrm{Cu}$ to $\mathrm{Ag}$ and then decreasing the value from $\mathrm{Ag}$ to $\mathrm{Au}$, respectively (except for $\mathrm{R}=2,6$ diisopropylphenyl).

Moreover, in the presence of the $\mathrm{Cu}$ and $\mathrm{Au}$ metal centers and changing the $\mathrm{R}$ substitutes from $\mathrm{F}$ to $\mathrm{Br}$ and also the partial natural charge value on $\mathrm{M}$ in $\left[\mathrm{Tgt} \rightarrow \mathrm{MPR}_{3}\right]$, unlike those obtained for $\left[\mathrm{Tgt} \rightarrow \mathrm{CuNHC}(\mathrm{R})\left(\mathrm{R}^{\prime}\right)\right]$ complexes increased. For, for example, in the presence of $\mathrm{F}, \mathrm{Cl}$, and $\mathrm{Br}$, the partial positive charge values for $\mathrm{Cu}$ atoms $\left[\mathrm{Tgt} \rightarrow \mathrm{CuPR}_{3}\right.$ ] are approximately $0.099 e, 0.247 e$, and $0.279 e$, respectively (see Table 3).

It is worth mentioning that in the presence of the same $\mathrm{R}$ substituent in $[$ Tgt $\rightarrow \operatorname{MNHC}(\mathrm{R})(\mathrm{H})]$, the partial natural charge value on the $\mathrm{M}$ metal center for $\mathrm{M}=\mathrm{Cu}$ and $\mathrm{Au}$ is slightly larger than that in $\left[\mathrm{Tgt} \rightarrow \mathrm{MPR}_{3}\right]$ complexes.

For example, the partial natural charge values on $\mathrm{Cu}$ atoms in $[\mathrm{Tgt} \rightarrow \mathrm{CuNHC}(\mathrm{H})(\mathrm{H})]$ and $\left[\mathrm{Tgt} \rightarrow \mathrm{CuPH}_{3}\right]$ are about 0.293 and 0.242 , respectively.

Notwithstanding, the largest charge values on the $\mathrm{M}$ metal center in $\left[\mathrm{Tgt} \rightarrow \mathrm{MNHC}(\mathrm{R})\left(\mathrm{R}^{\prime}\right)\right]$ and $\left[\mathrm{Tgt} \rightarrow \mathrm{MPR}_{3}\right]$ complexes are found in $[\mathrm{Tgt} \rightarrow \mathrm{CuNHC}(2,6-$ diisopropylphenyl $)(\mathrm{Ph})]$ and $\left[\mathrm{Tgt} \rightarrow \operatorname{AgP}\left(\mathrm{SiH}_{3}\right)_{3}\right]$ complexes, whereas the smallest values can be found in [Tgt $\rightarrow$ AuNHC(2,6-diisopropylphenyl)(H)] and [Tgt $\rightarrow \operatorname{AuP}(2,6-$ diisopropyl phenyl $)_{3}$ ] complexes, respectively.

It is worthy of note that the partial negative natural charge value of $S$ atoms in $\left[\right.$ Tgt $\left.\rightarrow \operatorname{MNHC}(\mathrm{R})\left(\mathrm{R}^{\prime}\right)\right]$ and $[$ Tgt $\rightarrow$ $\left.\mathrm{MPR}_{3}\right]$ complexes has also been addressed. The data confirm that the partial negative natural charge values of $S$ atoms in [Tgt $\rightarrow \mathrm{MPR}_{3}$ ] complexes are larger than those in $[\mathrm{Tgt} \rightarrow$ $\operatorname{MNHC}(\mathrm{R})\left(\mathrm{R}^{\prime}\right)$ ] complexes (See Table 3).

Charge-transfer $(\mathrm{CT})$ values from $[\mathrm{Tgt}]^{-}$to $[\mathrm{MNHC}(\mathrm{R})$ $\left.\left(\mathrm{R}^{\prime}\right)\right]^{+}$and $\left[\mathrm{MPR}_{3}\right]^{+}$fragments in $\left[\mathrm{Tgt} \rightarrow \mathrm{MNHC}(\mathrm{R})\left(\mathrm{R}^{\prime}\right)\right]$ and $\left[\mathrm{Tgt} \rightarrow \mathrm{MPR}_{3}\right]$ complexes are also analyzed.

As can be seen in Table 3, the CT values in [Tgt $\rightarrow$ $\left.\operatorname{MNHC}(\mathrm{R})\left(\mathrm{R}^{\prime}\right)\right]$ complexes, in the presence of the same $\mathrm{M}$ metal center and $R$ substitution, are greater than those in $[\mathrm{Tgt} \rightarrow$ $\left.\mathrm{MPR}_{3}\right]$ complexes, except for the 2,6-diisopropylphenyl substituent.

Results also demonstrate that, by changing the $\mathrm{R}$ substituent from the electron-donating to the electron-withdrawing groups, the values of CT are almost reduced in $\left[\mathrm{Tgt} \rightarrow \operatorname{MNHC}(\mathrm{R})\left(\mathrm{R}^{\prime}\right)\right]$ complexes (see Table 3 ). On the other hand, the maximum and minimum amounts of the $\mathrm{CT}$ in $\left[\mathrm{Tgt} \rightarrow \operatorname{MNHC}(\mathrm{R})\left(\mathrm{R}^{\prime}\right)\right]$ are found for $\left[\right.$ Tgt $\left.\rightarrow \mathrm{CuNHC}\left(\mathrm{CH}_{3}\right)(\mathrm{H})\right]$ and $[\mathrm{Tgt} \rightarrow$ AuNHC$(\mathrm{Br})(\mathrm{Ph})]$ complexes, respectively.

In $\left[\mathrm{Tgt} \rightarrow \mathrm{MPR}_{3}\right]$ complexes, the maximum and minimum amounts of the CT are also found in the case of [Tgt $\rightarrow$ $\left.\mathrm{CuP}(2,6 \text {-diisopropyl phenyl })_{3}\right]$ and $\left[\mathrm{Tgt} \rightarrow \operatorname{AgP}(\mathrm{Br})_{3}\right]$ complexes, respectively. 
Table 6. $\mathrm{EDA}^{a}$ Analysis (BP86-D3/TZ2P(ZORA)//PBE-D3/def2-TZVP) of the $\left[\mathrm{Tgt} \rightarrow \operatorname{MNHC}(\mathrm{R})\left(\mathrm{R}^{\prime}\right)\right]$ and $[\mathrm{Tgt} \rightarrow$ $\left.\mathrm{MP}(\mathrm{R})_{3}\right]$ Complexes $\left[\mathrm{M}=\mathrm{Au}(\mathrm{I}) ; \mathrm{R}=\mathrm{F}, \mathrm{Cl}, \mathrm{Br}, \mathrm{H}, \mathrm{CH}_{3}, \mathrm{C}_{2} \mathrm{H}_{5}, \mathrm{SiH}_{3}, 2,6\right.$-Diisopropylphenyl; $\mathrm{R}^{\prime}=\mathrm{H}$ and $\mathrm{Ph}$ ]

\begin{tabular}{|c|c|c|c|c|}
\hline $\mathrm{R}$ & & $\mathrm{Tgt} \rightarrow \operatorname{AuNHC}(\mathrm{R})(\mathrm{H})$ & $\mathrm{Tgt} \rightarrow \operatorname{AuP}(\mathrm{R})_{3}$ & $\mathrm{Tgt} \rightarrow \operatorname{AuNHC}(\mathrm{R})(\mathrm{Ph})$ \\
\hline \multirow[t]{8}{*}{$\mathrm{H}$} & $\Delta E_{\text {int }}$ & -163.71 & -177.38 & -156.91 \\
\hline & $\Delta E_{\text {pauli }}$ & 147.40 & 148.73 & 149.84 \\
\hline & $\Delta E_{\text {elast }}$ & $-216.39(69.55 \%)$ & $-226.53(72.80 \%)$ & $-209.74(68.37 \%)$ \\
\hline & $\Delta E_{\text {orb }}$ & $-86.03(27.65 \%)$ & $-90.40(24.70 \%)$ & $-86.69(26.69 \%)$ \\
\hline & $\Delta E_{\text {disper }}$ & $-8.69(2.79 \%)$ & $-9.17(2.50 \%)$ & $-10.32(3.37 \%)$ \\
\hline & $\Delta E_{\mathrm{orb}, \sigma}$ & -53.78 & -62.66 & -53.44 \\
\hline & $\Delta E_{\mathrm{orb}, \pi}$ & -23.62 & -16.23 & -23.95 \\
\hline & $\Delta E_{\text {orb,rest }}$ & -8.11 & -8.42 & -10.34 \\
\hline \multirow[t]{8}{*}{$\mathrm{F}$} & $\Delta E_{\text {int }}$ & $-163.03-$ & -198.73 & -161.07 \\
\hline & $\Delta E_{\text {pauli }}$ & 143.84 & 150.58 & 151.01 \\
\hline & $\Delta E_{\text {elast }}$ & $-217.93(69.70 \%)$ & $-238.17(68.20 \%)$ & $-214.05(68.59 \%)$ \\
\hline & $\Delta E_{\text {orb }}$ & $-89.31(28.60 \%)$ & $-101.38(29.10 \%)$ & $-90.19(28.90 \%)$ \\
\hline & $\Delta E_{\text {disper }}$ & $-5.63(1.80 \%)$ & $-9.76(2.80 \%)$ & $-7.84(2.51 \%)$ \\
\hline & $\Delta E_{\mathrm{orb}, \sigma}$ & -55.30 & -67.37 & -54.80 \\
\hline & $\Delta E_{\mathrm{orb}, \pi}$ & -25.75 & -20.32 & -26.03 \\
\hline & $\Delta E_{\text {orb,rest }}$ & -8.92 & -10.35 & -10.40 \\
\hline \multirow[t]{8}{*}{$\mathrm{Cl}$} & $\Delta E_{\text {int }}$ & -163.80 & -186.60 & -157.63 \\
\hline & $\Delta E_{\text {pauli }}$ & 145.42 & 154.55 & 152.09 \\
\hline & $\Delta E_{\text {elast }}$ & $-215.28(69.70 \%)$ & $-229.49(67.30 \%)$ & $-212.09(68.84 \%)$ \\
\hline & $\Delta E_{\text {orb }}$ & $-87.77(28.40 \%)$ & $-101.61(29.80 \%)$ & $-88.79(28.67 \%)$ \\
\hline & $\Delta E_{\text {disper }}$ & $-6.17(2.00 \%)$ & $-10.05(3.00 \%)$ & $-8.83(2.85 \%)$ \\
\hline & $\Delta E_{\mathrm{orb}, \sigma}$ & -54.05 & -69.61 & -53.61 \\
\hline & $\Delta E_{\mathrm{orb}, \pi}$ & -25.49 & -18.61 & -25.44 \\
\hline & $\Delta E_{\text {orb,rest }}$ & -9.13 & -9.86 & -10.61 \\
\hline \multirow[t]{8}{*}{$\mathrm{Br}$} & $\Delta E_{\text {int }}$ & -161.71 & -182.57 & -159.82 \\
\hline & $\Delta E_{\text {pauli }}$ & 145.58 & 156.70 & 154.54 \\
\hline & $\Delta E_{\text {elast }}$ & $-213.72(69.50 \%)$ & $-226.84(66.90 \%)$ & $-213.26(67.84 \%)$ \\
\hline & $\Delta E_{\text {orb }}$ & $-87.03(28.32 \%)$ & $-101.96(30.10 \%)$ & $-89.34(28.42 \%)$ \\
\hline & $\Delta E_{\text {disper }}$ & $-6.55(2.10 \%)$ & $-10.46(3.10 \%)$ & $-11.76(3.74 \%)$ \\
\hline & $\Delta E_{\mathrm{orb}, \sigma}$ & -53.46 & -69.58 & -51.39 \\
\hline & $\Delta E_{\mathrm{orb}, \pi}$ & -24.58 & -18.10 & -25.40 \\
\hline & $\Delta E_{\text {orb,rest }}$ & -9.65 & -10.00 & -10.82 \\
\hline \multirow[t]{8}{*}{$\mathrm{CH}_{3}$} & $\Delta E_{\text {int }}$ & -160.63 & -158.60 & -152.76 \\
\hline & $\Delta E_{\text {pauli }}$ & 149.02 & 158.35 & 153.84 \\
\hline & $\Delta E_{\text {elast }}$ & $-216.84(69.60 \%)$ & $-216.36(68.30 \%)$ & $-210.29(68.59 \%)$ \\
\hline & $\Delta E_{\text {orb }}$ & $-82.43(26.50 \%)$ & $-86.36(27.30 \%)$ & $-86.50(28.21 \%)$ \\
\hline & $\Delta E_{\text {disper }}$ & $-10.39(4.10 \%)$ & $-14.24(4.50 \%)$ & $-9.82(3.20 \%)$ \\
\hline & $\Delta E_{\mathrm{orb}, \sigma}$ & -49.56 & -58.04 & -52.72 \\
\hline & $\Delta E_{\mathrm{orb}, \pi}$ & -21.22 & -13.63 & -23.37 \\
\hline & $\Delta E_{\text {orb,rest }}$ & -10.69 & -12.57 & -10.74 \\
\hline \multirow[t]{8}{*}{$\mathrm{SiH}_{3}$} & $\Delta E_{\text {int }}$ & -165.90 & -162.85 & -153.89 \\
\hline & $\Delta E_{\text {pauli }}$ & 150.06 & 159.45 & 153.09 \\
\hline & $\Delta E_{\text {elast }}$ & $-217.41(68.80 \%)$ & $-217.55(67.50 \%)$ & $-208.54(67.93 \%)$ \\
\hline & $\Delta E_{\text {orb }}$ & $-85.08(27.00 \%)$ & $-89.98(28.00 \%)$ & $-87.52(28.51 \%)$ \\
\hline & $\Delta E_{\text {disper }}$ & $-13.53(4.30 \%)$ & $-14.77(4.60 \%)$ & $-10.92(3.56 \%)$ \\
\hline & $\Delta E_{\mathrm{orb}, \sigma}$ & -50.73 & -61.52 & -52.85 \\
\hline & $\Delta E_{\mathrm{orb}, \pi}$ & -21.66 & -13.86 & -23.32 \\
\hline & $\Delta E_{\text {orb,rest }}$ & -12.04 & -10.57 & -11.65 \\
\hline \multirow[t]{12}{*}{ 2,6-diisopropyl phenyl } & $\Delta E_{\text {int }}$ & -156.25 & -141.76 & -151.75 \\
\hline & $\Delta E_{\text {pauli }}$ & 156.86 & 164.97 & 157.36 \\
\hline & $\Delta E_{\text {elast }}$ & $-210.25(67.20 \%)$ & $-200.14(65.25 \%)$ & $-206.60(66.84 \%)$ \\
\hline & $\Delta E_{\text {orb }}$ & $-84.61(27.10 \%)$ & $-87.16(28.42 \%)$ & $-84.68(27.39 \%)$ \\
\hline & $\Delta E_{\text {disper }}$ & $-18.25(5.90 \%)$ & $-19.43(6.33 \%)$ & $-17.83(5.77 \%)$ \\
\hline & $\Delta E_{\mathrm{orb}, \sigma}$ & -50.08 & -61.50 & -49.76 \\
\hline & $\Delta E_{\mathrm{orb}, \pi}$ & -22.58 & -11.42 & -22.45 \\
\hline & $\Delta E_{\text {orb,rest }}$ & -13.53 & -12.21 & -13.40 \\
\hline & $\Delta E_{\text {int }}$ & & -153.07 & \\
\hline & $\Delta E_{\text {pauli }}$ & & 158.47 & \\
\hline & $\Delta E_{\text {elast }}$ & & $-213.88(68.65 \%)$ & \\
\hline & $\Delta E_{\text {orb }}$ & & $-85.54(27.46 \%)$ & \\
\hline
\end{tabular}


Table 6. continued

\begin{tabular}{|c|c|c|c|c|}
\hline & & $\mathrm{Tgt} \rightarrow \operatorname{AuNHC}(\mathrm{R})(\mathrm{H})$ & $\mathrm{Tgt} \rightarrow \operatorname{AuP}(\mathrm{R})_{3}$ & $\mathrm{Tgt} \rightarrow \operatorname{AuNHC}(\mathrm{R})(\mathrm{Ph})$ \\
\hline \multirow[t]{4}{*}{$\mathrm{C}_{2} \mathrm{H}_{5}$} & $\Delta E_{\text {disper }}$ & & $-12.13(3.89 \%)$ & \\
\hline & $\Delta E_{\mathrm{orb}, \sigma}$ & & -57.01 & \\
\hline & $\Delta E_{\mathrm{orb}, \pi}$ & & -13.43 & \\
\hline & $\Delta E_{\text {orb,rest }}$ & & -12.95 & \\
\hline
\end{tabular}

${ }^{a}$ All energy values are at $\mathrm{kcal} \mathrm{mol}^{-1}$.

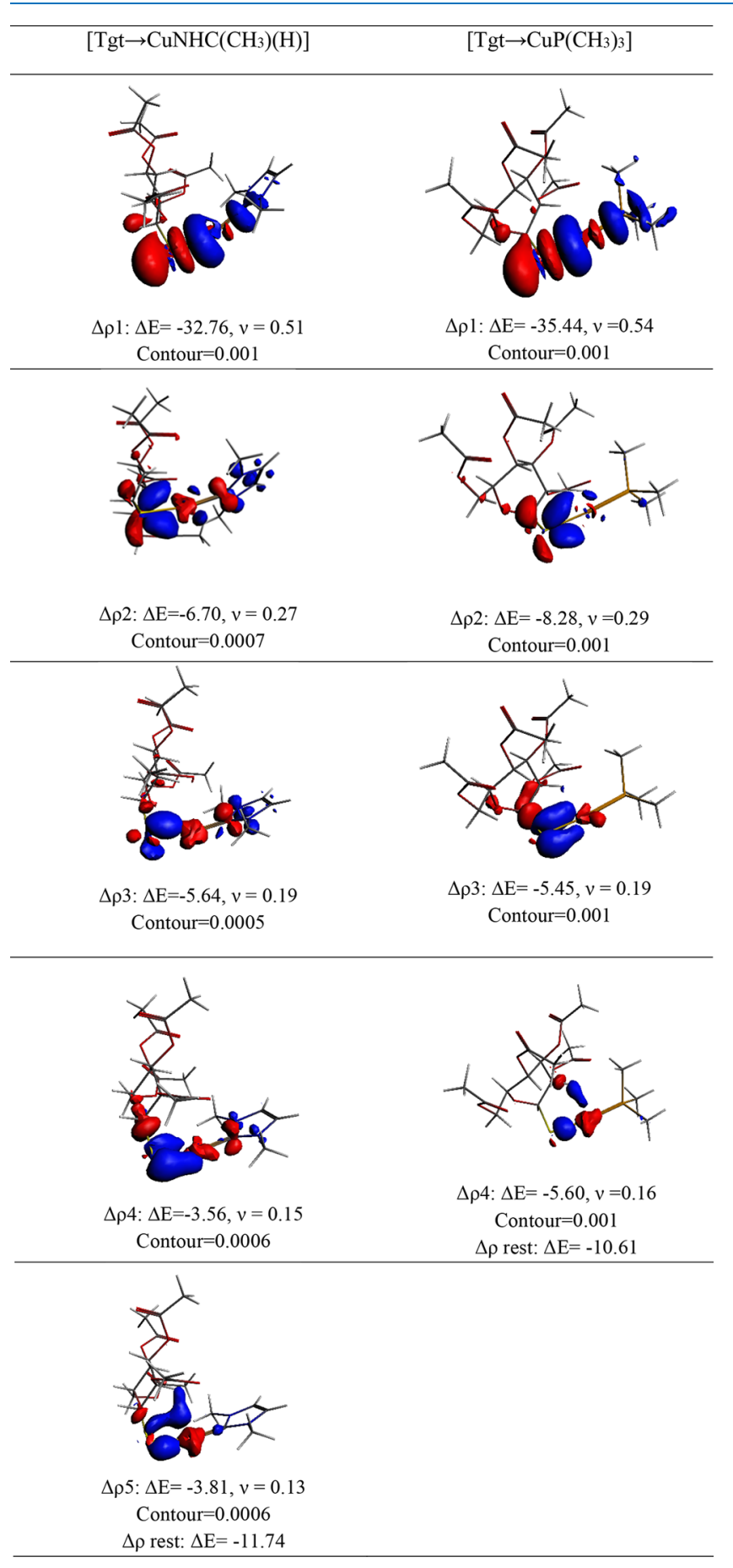

Figure 6. Deformation densities associated with the most important orbital interactions for $\left[\mathrm{Tgt} \rightarrow \mathrm{CuNHC}\left(\mathrm{CH}_{3}\right)(\mathrm{H})\right]$ and $[\mathrm{Tgt} \rightarrow$ $\left.\mathrm{CuP}\left(\mathrm{CH}_{3}\right)_{3}\right]$ complexes at the BP86-D3/TZ2P(ZORA)//PBE-D3/ def2-TZVP level of theory.

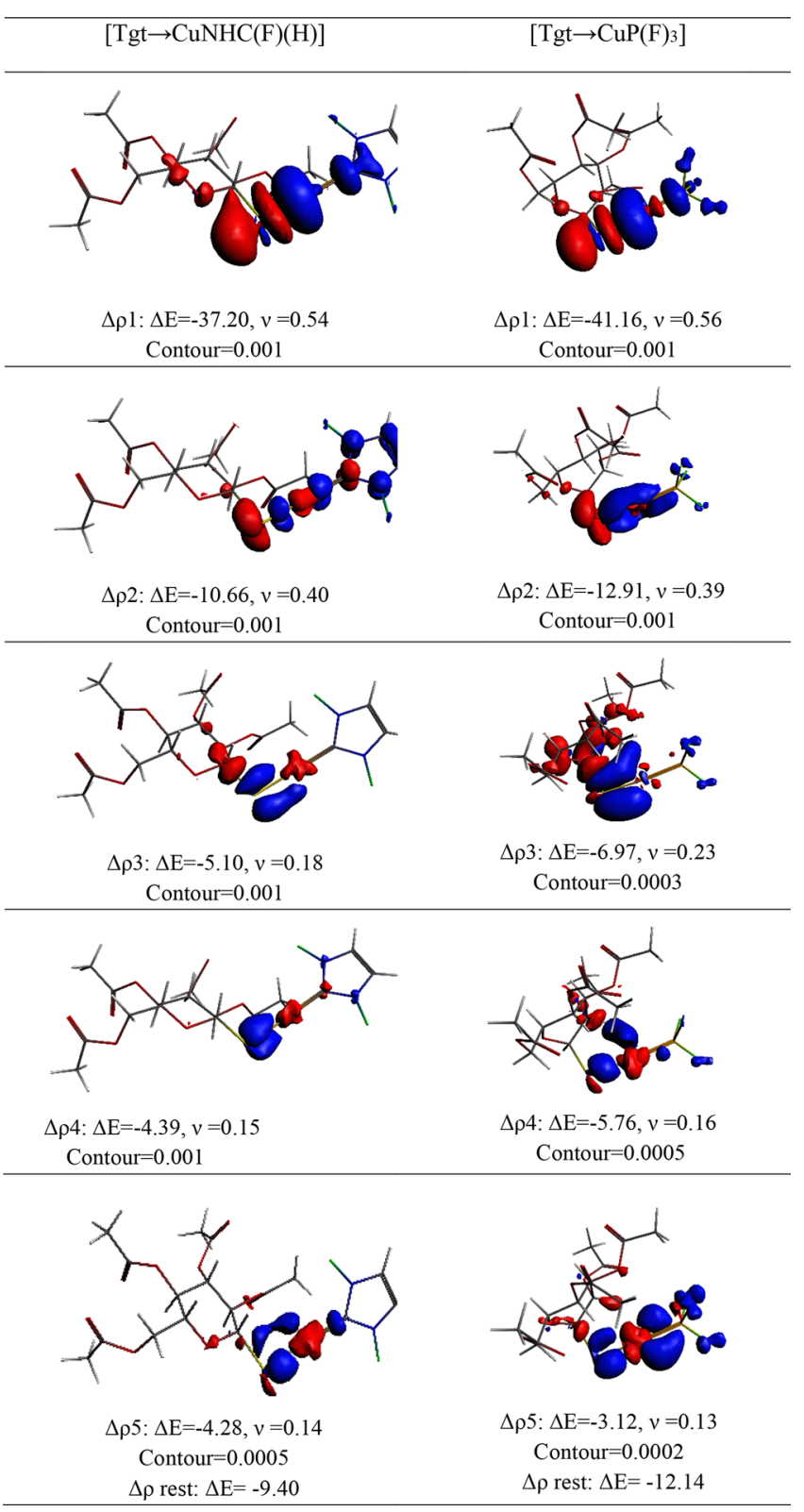

Figure 7. Deformation densities associated with the most important orbital interactions for $[\mathrm{Tgt} \rightarrow \mathrm{CuNHC}(\mathrm{F})(\mathrm{H})]$ and $\left[\mathrm{Tgt} \rightarrow \mathrm{CuP}(\mathrm{F})_{3}\right]$ complexes at the BP86-D3/TZ2P(ZORA)//PBE-D3/def2-TZVP level of theory.

Finally, in the case of [Tgt $\left.\rightarrow \mathrm{MPR}_{3}\right]$ complexes, the wellknown v-shaped attitude is shown for the CT values by considering the same $\mathrm{R}$ substituent and by changing the $\mathrm{M}$ metal center from $\mathrm{Cu}$ to $\mathrm{Au}$ in most cases and in compliance with the interaction energies $\left(\Delta E_{\text {int }}\right)$ in the following order: $\mathrm{Ag}<\mathrm{Cu} \sim$ $\mathrm{Au}$. 
Using the Wiberg bond index (WBI) method, the chemical bond orders of $\mathrm{M} \leftarrow \mathrm{P}$ and $\mathrm{M} \leftarrow \mathrm{S}$ bonds in [Tgt $\rightarrow \mathrm{MPR}_{3}$ ] complexes and $\mathrm{M} \leftarrow \mathrm{C}$ and $\mathrm{M} \leftarrow \mathrm{S}$ bonds in [Tgt $\rightarrow$ $\left.\operatorname{MNHC}(\mathrm{R})\left(\mathrm{R}^{\prime}\right)\right]$ are also evaluated and as can be seen, the results are compared in the Table 3 .

The obtained results have shown that by changing the $M$ metal center in the presence of the same $R$ and $R^{\prime}$ substituents in $\left[\mathrm{Tgt} \rightarrow \operatorname{MNHC}(\mathrm{R})\left(\mathrm{R}^{\prime}\right)\right]$ complexes, which are in good agreement with the interaction energies $\left(\Delta E_{\text {int }}\right)$, the wellknown v-shaped attitude is shown for the WBI values of the $M$ $\leftarrow \mathrm{C}$ bond in the following order: $\mathrm{Ag}(\mathrm{I})<\mathrm{Cu}(\mathrm{I})<\mathrm{Au}(\mathrm{I})$. Moreover, it is found that changing the $\mathrm{R}^{\prime}$ substituent has no significant effect on the WBI values of $\mathrm{M} \leftarrow \mathrm{C}$ bonds (see Table 3).

Afterward, by changing the $\mathrm{R}$ substituent from electrondonating to electron-withdrawing substituent, we can see an increase in the values of WBI's $M \leftarrow S$ in [Tgt $\rightarrow$ $\operatorname{MNHC}(\mathrm{R})(\mathrm{H})]$ and $\left[\mathrm{Tgt} \rightarrow \mathrm{MPR}_{3}\right]$ complexes.

Generally, the values of WBI's $\mathrm{M} \leftarrow \mathrm{S}$ in $\left[\mathrm{Tgt} \rightarrow \mathrm{MPR}_{3}\right]$ complexes are slightly larger than those in $[\mathrm{Tgt} \rightarrow \mathrm{MNHC}(\mathrm{R})$ (H)] complexes; Nonetheless, 2,6-diisopropylphenyl complexes are some examples of their exceptions. The obtained data showed that the smallest values of WBIs for $\mathrm{M} \leftarrow \mathrm{C}$ and $\mathrm{M} \leftarrow \mathrm{P}$ bonds in the complexes are found in $[\mathrm{Tgt} \rightarrow \operatorname{AgNHC}(2,6-$ diisopropylphenyl $)(\mathrm{Ph})]$ and [Tgt $\rightarrow \operatorname{AgP}(2,6$-diisopropylphenyl $)_{3}$ ] complexes and those for $\mathrm{M} \leftarrow \mathrm{S}$ bonds are found in $\left[\mathrm{Tgt} \rightarrow \operatorname{AgNHC}\left(\mathrm{SiH}_{3}\right)(\mathrm{H})\right]$ and $\left.\left.[\mathrm{Tgt} \rightarrow \operatorname{AgP}) \mathrm{C}_{2} \mathrm{H}_{5}\right)\right]$ complexes.

Based on the above findings, which are in good agreement with the metal-drug $(\mathrm{M} \leftarrow S)$ bond $\Delta E_{\text {int }}$ it can be concluded that in comparison with $\mathrm{PR}_{3}$ ligands and $\mathrm{Cu}$ and $\mathrm{Au}$ metal centers in the complexes examined here, drug releases are better facilitated in the presence of the majority of $\mathrm{NHC}(\mathrm{R})(\mathrm{R})$ ligands and $\mathrm{Ag}$ metal center. Conversely, 2,6-diisopropylphenyl complexes can be considered as exceptions.

The Fock matrix has been used in this sense to analyze donor-acceptor interactions based on an NBO analysis.

Tables S9-S20 demonstrate the values of the donoracceptor interactions as well as natural hybrid orbital (NHO) analysis for the electron-donating and electron-withdrawing substituents on the complexes investigated, and also the results of natural hybrid orbital (NHO) analysis between the $\mathrm{M}$ metal center and $\mathrm{S}, \mathrm{P}$, and $\mathrm{C}$ atoms in $\mathrm{M} \leftarrow \mathrm{S}, \mathrm{M} \leftarrow \mathrm{P}$, and $\mathrm{M} \leftarrow \mathrm{C}$ bonds in $\left[\mathrm{Tgt} \rightarrow \mathrm{MNHC}(\mathrm{R})\left(\mathrm{R}^{\prime}\right)\right]$ and $\left[\mathrm{Tgt} \rightarrow \mathrm{MPR}_{3}\right]$ complexes are represented. Apart from that, the occupancy of $\mathrm{S}, \mathrm{P}$, and $\mathrm{C}$ atoms in the latter bonds are $\simeq 80 \%$ in the presence of $\mathrm{Cu}(\mathrm{I})$ and $\mathrm{Ag}(\mathrm{I})$, and $\simeq 70 \%$ in the presence of $\mathrm{Au}(\mathrm{I})$ metal centers, respectively. The proof obtained confirmed the existence of $\sigma$ bonding interactions between the lone pair of sulfur and the carbon atoms of $[\mathrm{Tgt}]^{-}$and carbene as the Lewis base to the empty orbitals of the M-metal center as the Lewis acid (see Tables S9-S17). The modification of the R substituent does not have a significant impact on the occupancy values of $S$, $\mathrm{P}$, and $\mathrm{C}$ atoms in the latter bonds in $\left[\mathrm{Tgt} \rightarrow \operatorname{MNHC}(\mathrm{R})\left(\mathrm{R}^{\prime}\right)\right]$ $[\mathrm{M}=\mathrm{Cu}(\mathrm{I}), \mathrm{Ag}(\mathrm{I})$, and $\mathrm{Au}(\mathrm{I})]$ complexes (see Tables S9-S17). It is also worth noting that the results of the second-order perturbation theory analysis showed that the $\sigma^{*}$ and $\mathrm{Lp}^{*}$ orbitals of the $M$ metal center in $M \leftarrow S, M \leftarrow P$, and $M \leftarrow C$ bonds are filled with lone-pair electrons of $\mathrm{S}, \mathrm{P}$, and $\mathrm{C}$ atoms as the $\sigma$ orbitals of $\mathrm{M} \leftarrow \mathrm{S}, \mathrm{M} \leftarrow \mathrm{P}$, and $\mathrm{M} \leftarrow \mathrm{C}$ bonds $[\mathrm{M}=\mathrm{Cu}(\mathrm{I})]$. In this sense, $\mathrm{Ag}(\mathrm{I})$ and $\mathrm{Au}(\mathrm{I})$ in the complexes can be attributed to the $\pi$-back-donation (see Tables S18-S20).
3.5. EDA Analysis. Energy decomposition analysis (EDA) for obtaining information on driving forces contributing to the molecular structure and reactivity should be seen as an essential tool for the quantitative interpretation of chemical bonds. In this regard, the nature of metal-ligand bonds is analyzed by partitioning the bonds into ionic and covalent components. ${ }^{33}$

It should be noted that the energy decomposition analysis (EDA), developed by Morokuma ${ }^{38}$ and Ziegler, ${ }^{39,40}$ is in conjunction with the charging decomposition method; Natural Orbital for Chemical Valence (NOCV). ${ }^{41,42}$

In order to analyze the nature of the bond in organic and inorganic compounds, the EDA focuses on the instantaneous energy interaction $\left(\Delta E_{\text {int }}\right)$ of two or more chemical bonds between the fragments in the specific electronic reference state and the frozen molecular geometry. ${ }^{43,44}$

The interaction energy can be divided into four main components eq 1 .

$$
\Delta E_{\text {int }}=\Delta E_{\text {elstat }}+\Delta E_{\text {orb }}+\Delta E_{\text {Pauli }}+\Delta E_{\text {disp }}
$$

where $\Delta E_{\text {elstat }}$ is the electrostatic interaction, $\Delta E_{\text {orb }}$ is the orbital interaction, $\Delta E_{\text {pauli }}$ is Pauli repulsion, and $\Delta E_{\text {disp }}$ is the dispersion energy between the two investigated fragments.

In this research, the bonding analysis is defined as the interaction between $[\mathrm{MNHC}(\mathrm{R})(\mathrm{R})]^{+}$and $\left[\mathrm{MPR}_{3}\right]^{+}$with $[\mathrm{Tgt}]^{-}$fragments in the related optimized structures.

According to this analysis, the optimized structure of the [Tgt $\left.\rightarrow \mathrm{MNHC}(\mathrm{R})\left(\mathrm{R}^{\prime}\right)\right]$ and $\left[\mathrm{Tgt} \rightarrow \mathrm{MPR}_{3}\right]\{\mathrm{M}=\mathrm{Cu}(\mathrm{I}), \mathrm{Ag}(\mathrm{I})$, $\mathrm{Au}(\mathrm{I}) ; \mathrm{R}=\mathrm{F}, \mathrm{Cl}, \mathrm{Br}, \mathrm{H}, \mathrm{CH}_{3}, \mathrm{C}_{2} \mathrm{H}_{5}, \mathrm{SiH}_{3}$, 2,6-diisopropylphenyl; $\mathrm{R}^{\prime}=\mathrm{H}$ and $\mathrm{Ph}$ [as these substituents are given on two noncarbenic carbon atoms $\left(\mathrm{C}_{4}\right.$ and $\left.\mathrm{C}_{5}\right)$ in the heterocycle]\} complexes (Scheme 1) are performed with BP86-D3/TZ2P(ZORA)//PBE-D3/def2-TZVP and the program package ADF2009.01. As can be seen in Tables 4-6, the results obtained indicate that $\Delta E_{\text {int }}$ values of the studied complexes are identical to those obtained at PBE-D3/def2-TZVP.

Tables 4-6 represent the results of energy decomposition analysis (EDA) for $\left[\mathrm{Tgt} \rightarrow \operatorname{MNHC}(\mathrm{R})\left(\mathrm{R}^{\prime}\right)\right]$ and $[$ Tgt $\rightarrow$ $\mathrm{MPR}_{3}$ ] complexes.

According to the EDA results for $\left[\right.$ Tgt $\left.\rightarrow \operatorname{MNHC}(\mathrm{R})\left(\mathrm{R}^{\prime}\right)\right]$ complexes with $\mathrm{R}^{\prime}=\mathrm{H}$ and $\mathrm{Ph}$ (as these substituents are given on two noncarbenic carbon atoms $\left(\mathrm{C}_{4}\right.$ and $\left.\mathrm{C}_{5}\right)$ in the heterocycle) complexes, it can be inferred that changing the $\mathrm{R}$ group from $\mathrm{H}$ to $\mathrm{Ph}$ has a relatively remarkable impact on the amount of interaction energy and also, in the plurality of cases for the same $\mathrm{R}$ substitution in $[\mathrm{Tgt} \rightarrow \operatorname{MNHC}(\mathrm{R})(\mathrm{Ph})]$ complexes, the amount of interaction energy is less than the corresponding value in $[\mathrm{Tgt} \rightarrow \operatorname{MNHC}(\mathrm{R})(\mathrm{H})]$ complexes (see Tables 4-6).

The results illustrate that the smallest values of $\Delta E_{\text {int }}$ in the complexes correspond to electron-donating substitutions (often 2, 6-diisopropylphenyl) and the greatest values correspond to the electron-withdrawing changes (mostly F) (see Tables 4-6).

In addition, in accordance with what has been addressed in Section 3.2 in the presence of the electron-withdrawing substituents $\mathrm{F}, \mathrm{Cl}$, and $\mathrm{Br}$ and by considering the same $\mathrm{M}$ atom and changing the $\mathrm{L}$ ligand from $\mathrm{NHC}(\mathrm{R})\left(\mathrm{R}^{\prime}\right)$ to $\mathrm{PR}_{3}$, the strength of the $\mathrm{M} \leftarrow \mathrm{S}$ bond in [Tgt $\rightarrow \mathrm{ML}$ ] complexes has increased. For example, as can be seen in Table 4, in the case of [Tgt $\rightarrow \mathrm{CuL}]$ complex, the $\Delta E_{\text {int }}$ values in the presence of $\mathrm{NHC}(\mathrm{F})(\mathrm{H} / \mathrm{Ph})$ ligands are approximately 162.6 and 155.6 $\mathrm{kcal} \mathrm{mol}^{-1}$ and by changing the $\mathrm{L}$ ligand group to $\mathrm{PF}_{3}$, the $\Delta E_{\text {int }}$ value is approximately $186.7 \mathrm{kcal} \mathrm{mol}^{-1}$ (see Table 4). Therefore, the findings obtained suggested once again that 
drug releases are more facilitated in the presence of $\mathrm{NHC}(\mathrm{R})$ $\left(\mathrm{R}^{\prime}\right)$ ligands than the $\mathrm{PR}_{3}$ ligands studied here.

The EDA analysis results reveal that among the three attractive terms of energy decomposition analysis, the electrostatic energy $\Delta E_{\text {elstat }}$ is the most critical energy with about 64$74 \%$. Subsequently, $\Delta E_{\text {orb }}$ comes with a percentage in the range $\sim 22-30 \%$ and $\Delta E_{\text {disp, }}$ which arises from the instantaneous dipole-induced dipole forces between the two fragments having a little effect (about 2-9\%) on $\Delta E_{\text {int }}$ (see Tables 4-6).

The covalent bond between the two interacted fragments of $\left[\mathrm{MNHC}(\mathrm{R})\left(\mathrm{R}^{\prime}\right)\right]^{+}$with $[\mathrm{Tgt}]^{-}$and also $\left[\mathrm{MPR}_{3}\right]^{+}$with $[\mathrm{Tgt}]^{-}$ fragments in the optimized structure of the [Tgt $\rightarrow$ MNHC$\left.(\mathrm{R})\left(\mathrm{R}^{\prime}\right)\right]$ and $\left[\mathrm{Tgt} \rightarrow \mathrm{MPR}_{3}\right]\{\mathrm{M}=\mathrm{Cu}(\mathrm{I}), \mathrm{Ag}(\mathrm{I}), \mathrm{Au}(\mathrm{I}) ; \mathrm{R}=\mathrm{F}$, $\mathrm{Cl}, \mathrm{Br}, \mathrm{H}, \mathrm{CH}_{3}, \mathrm{C}_{2} \mathrm{H}_{5}, \mathrm{SiH}_{3}, 2$,6-diisopropylphenyl; $\mathrm{R}^{\prime}=\mathrm{H}$ and $\mathrm{Ph}$ [as these substituents are given on two noncarbenic carbon atoms $\left(\mathrm{C}_{4}\right.$ and $\left.\mathrm{C}_{5}\right)$ in the heterocycle $\left.]\right\}$ complexes is rendered apparent by the measured deformation densities $\Delta \rho$. This function can be associated with significant orbital interactions between the fragments described above.

Using the EDA-NOCV method, the individual portions of the pairwise interactions are determinable. It should be remembered that there are only a few numbers of pairwise encounters that make a major contribution to $\Delta E_{\text {orb}}$.

Regarding [Tgt $\left.\rightarrow \operatorname{MNHC}(\mathrm{R})\left(\mathrm{R}^{\prime}\right)\right]$ and $\left[\mathrm{Tgt} \rightarrow \mathrm{MPR}_{3}\right]$ complexes, the NOCV pairs account for an average of 69.3$90.8 \%$ and $75.2-87.3 \%$ of $\Delta E_{\text {orb }}$, respectively. Figures 6 and 7 illustrate the critical deformation densities and the associated energy values for $[\mathrm{Tgt} \rightarrow \mathrm{CuNHC}(\mathrm{R})(\mathrm{H})]$ and $\left[\mathrm{Tgt} \rightarrow \mathrm{CuPR}_{3}\right]$ $\left(\mathrm{R}=\mathrm{F}\right.$ and $\left.\mathrm{CH}_{3}\right)$ complexes. The Supporting Information gives the deformation densities for the other complexes (see Figures $\mathrm{S} 1-\mathrm{S} 22)$. As seen in the figures as mentioned above, the dominant term of $\Delta E_{\text {orb }}$ for $[$ Tgt $\rightarrow \operatorname{CuNHC}(\mathrm{R})(\mathrm{H})]$ and $[\mathrm{Tgt}$ $\left.\rightarrow \mathrm{CuPR}_{3}\right]$ complexes emerges from the $\sigma$-orbital interactions.

According to Figures 6 and 7, in all complexes investigated here, the shapes of the orbital pair $\Delta \rho 1$ show the sigma orbital interaction between the lone pair of $S$ atom of $[\mathrm{Tgt}]^{-}$fragment as the donor and the empty orbital of $\mathrm{M}$ atom in $\mathrm{MNHC}(\mathrm{R})\left(\mathrm{R}^{\prime}\right)$ and $\mathrm{MPR}_{3}$ fragments as the acceptor (see Figures 6 and 7 ).

On the other hand, the shapes of $\Delta \rho 4$ indicate the $\sigma$-backdonation $\left(\sigma_{\mathrm{bd}}\right)$ from the $\mathrm{dz}^{2}$ orbital at $\mathrm{M}$ atom to the [Tgt] fragment in $\left[\mathrm{Tgt} \rightarrow \mathrm{CuPR}_{3}\right]\left(\mathrm{R}=\mathrm{F}\right.$, and $\left.\mathrm{CH}_{3}\right)$ complexes. According to obtained results, the $\sigma$-orbital interactions which account for $\left[\mathrm{Tgt} \rightarrow \mathrm{CuPR}_{3}\right]$ and $[\mathrm{Tgt} \rightarrow \mathrm{CuNHC}(\mathrm{R})(\mathrm{H})](\mathrm{R}=$ $\mathrm{F}$ and $\left.\mathrm{CH}_{3}\right)$ complexes are approximately $50.5 \%-53.1 \%$ and $57.6 \%-58.9 \%$ of the $\Delta E_{\text {orb }}$ term (see Figures 6 and 7 ). Likewise, in these complexes, the $\pi$ and $\pi$-back-donation constitute approximately $19.7-27.6 \%$ of $\Delta E_{\text {orb }}$ term. In this regard, $\Delta \rho 2$, $\Delta \rho 3$, and $\Delta \rho 5$ are attributed to the associated energy stabilization for the two $\pi$ and $\pi$-back-donations, where $\Delta \rho 2$ is out of plan and $\Delta \rho 3$ and $\Delta \rho 5$ are in plan (see Tables 4-6 and Figures 6 and 7). It should be said that the shapes of $\Delta \rho 2-\Delta \rho 5$ in $[\mathrm{Tgt} \rightarrow \mathrm{CuNHC}(\mathrm{R})(\mathrm{H})]\left(\mathrm{R}=\mathrm{F}\right.$, and $\left.\mathrm{CH}_{3}\right)$ complexes which indicate the $\pi$-back-donation constitute approximately 30.4$34.9 \%$ of $\Delta E_{\text {orb }}$ term in $[\mathrm{Tgt} \rightarrow \mathrm{CuNHC}(\mathrm{R})(\mathrm{H})](\mathrm{R}=\mathrm{F}$, and $\left.\mathrm{CH}_{3}\right)$ complexes and they show that the $\Delta \rho 2$ and $\Delta \rho 4$ are out of plan and $\Delta \rho 3$ and $\Delta \rho 5$ are in plan (see Tables $4-6$ and Figures 6 and 7). The obtained results confirm that in comparison to [Tgt $\left.\rightarrow \operatorname{MNHC}(\mathrm{R})\left(\mathrm{R}^{\prime}\right)\right]$ complexes, the interactions between the $\mathrm{S}$ atom of $[\mathrm{Tgt}]^{-}$fragment and $\mathrm{M}$ atoms of $\mathrm{MPR}_{3}$ fragments in $\left[\mathrm{Tgt} \rightarrow \mathrm{MPR}_{3}\right]$ complexes can be regarded as better $\sigma$ donors. Moreover, they can also be considered as weaker $\pi$ acceptors than the corresponding values in $\left[\right.$ Tgt $\left.\rightarrow \operatorname{MNHC}(\mathrm{R})\left(\mathrm{R}^{\prime}\right)\right]$ complexes.

\section{CONCLUSIONS}

The present study outlines a theoretical analysis on the complexes of the group 11 metals with general formula [Tgt $\rightarrow \mathrm{ML}]$ in coordination with symmetrical unsaturated $\mathrm{N}$ heterocyclic carbenes $\left[\mathrm{NHC}(\mathrm{R})\left(\mathrm{R}^{\prime}\right)\right]$ and monodentate phosphine $\left(\mathrm{PR}_{3}\right)$ [where $\mathrm{M}=\mathrm{Cu}(\mathrm{I}), \mathrm{Ag}(\mathrm{I}), \mathrm{Au}(\mathrm{I})$, Tgt = 2,3,4,6-tetra-O-acetyl-1-thio- $\beta$-D-glucopyranoside, L = NHC$(\mathrm{R})\left(\mathrm{R}^{\prime}\right)$ and $\mathrm{PR}_{3} ; \mathrm{R}=\mathrm{F}, \mathrm{Cl}, \mathrm{Br}, \mathrm{H}, \mathrm{CH}_{3}, \mathrm{C}_{2} \mathrm{H}_{5}, \mathrm{SiH}_{3}, 2,6-$ diisopropylphenyl; $\mathrm{R}^{\prime}=\mathrm{H}$ and $\mathrm{Ph}$ ] at PBE-D3/def2-TZVP. The $\mathrm{R}^{\prime}$ substitutes are located on two noncarbenic carbon atoms $\left(\mathrm{C}_{4}\right.$ and $\mathrm{C}_{5}$ ) in the heterocycle complexes. Data obtained from rms statistical results among eight density functional methods have shown that PBE-D3 is the most appropriate function among these methods.

The $\Delta E_{\text {int }}$ values of the metal-drug $(\mathrm{M} \leftarrow \mathrm{S})$ bond in [Tgt $\rightarrow$ $\left.\mathrm{MNHC}(\mathrm{R})\left(\mathrm{R}^{\prime}\right)\right]$ and $\left[\mathrm{Tgt} \rightarrow \mathrm{MPR}_{3}\right.$ ] complexes confirmed that the drug releases are more facilitated in the presence of $\mathrm{NHC}(\mathrm{R})(\mathrm{Ph})$ ligand than $\mathrm{PR}_{3}$ ligands studied here. In addition, it can be inferred that the group 11 metals form stronger bonds with the $[\mathrm{Tgt}]^{-}$drug in the $\left[\mathrm{Tgt} \rightarrow \mathrm{MPR}_{3}\right]$ form than $[\mathrm{Tgt} \rightarrow$ $\left.\operatorname{MNHC}(\mathrm{R})\left(\mathrm{R}^{\prime}\right)\right]$ complexes in the presence of the same $M$ metal ion and $\mathrm{R}=\mathrm{F}, \mathrm{Cl}, \mathrm{Br}$, and $\mathrm{H}$ substituents, The WBIs which were in good agreement with $\Delta E_{\text {int }}$ of metal-drug $(\mathrm{M} \leftarrow \mathrm{S})$ bond confirmed that the drug releases were more facilitated in the presence of most of the $\mathrm{NHC}(\mathrm{R})\left(\mathrm{R}^{\prime}\right)$ ligands and Ag metal center than $\mathrm{PR}_{3}$ ligands and $\mathrm{Cu}$ and $\mathrm{Au}$ metal centers in the complexes.

The results of EDA, which were in agreement with $\mathrm{NBO}$ and $\Delta E_{\text {int }}$ of metal-drug $(\mathrm{M} \leftarrow S)$ bond, not only confirmed that the drug releases were more facilitated in the presence of $\mathrm{NHC}(\mathrm{R})\left(\mathrm{R}^{\prime}\right)$ ligands than $\mathrm{PR}_{3}$ ligands for electron-withdrawing substituents but also confirmed that the electrostatic energy $\Delta E_{\text {elstat }}$ was the most important energy among the three attractive terms of an energy decomposition analysis with about $64-74 \%$ in all the complexes. The EDA-NOCV confirmed that the interactions between the $S$ atoms of the $[\mathrm{Tgt}]^{-}$fragment and $\mathrm{M}$ atoms of $\mathrm{M}-\mathrm{PR}_{3}$ fragments in [Tgt $\rightarrow$ $\left.\mathrm{MPR}_{3}\right]$ complexes are better $\sigma$ donors. Furthermore, they can be regarded as weaker $\pi$ acceptors than the corresponding values in those of $\left[\right.$ Tgt $\rightarrow$ MNHC(R)( $\left.\left.\mathrm{R}^{\prime}\right)\right]$ complexes.

\section{ASSOCIATED CONTENT}

\section{Supporting Information}

The Supporting Information is available free of charge at https://pubs.acs.org/doi/10.1021/acsomega.0c01471.

Cartesian coordinates, calculated $\mathrm{M}-\mathrm{C}$ and $\mathrm{M}-\mathrm{S}$ bond lengths, topological properties critical points of $\mathrm{M}-\mathrm{C}$ and $\mathrm{M}-\mathrm{S}$ bonds, and uncorrected $\Delta E_{\text {int }}$ investigated here (PDF)

\section{AUTHOR INFORMATION}

\section{Corresponding Author}

Mehdi Bayat - Department of Inorganic Chemistry, Faculty of Chemistry, Bu-Ali Sina University, Hamedan 6516738695, Iran; (1) orcid.org/0000-0002-5032-6522; Phone: +98-813828-2807; Email: mbayat@basu.ac.ir(mehdi806@ gmail.com; Fax: +98-813-838-0709

\section{Author}

Bahareh Naderizadeh - Department of Inorganic Chemistry, Faculty of Chemistry, Bu-Ali Sina University, Hamedan 6516738695, Iran 
Complete contact information is available at:

https://pubs.acs.org/10.1021/acsomega.0c01471

\section{Notes}

The authors declare no competing financial interest.

\section{ACKNOWLEDGMENTS}

The authors acknowledge the Bu-Ali Sina University Research Councils for the financial support of this work.

\section{REFERENCES}

(1) Hahn, F. E.; Jahnke, M. C. Heterocyclic carbenes: Synthesis and coordination chemistry. Angew. Chem., Int. Ed. Engl. 2008, 47, 31223172 .

(2) Petz, W.; Frenking, G. Carbodiphosphoranes and Related Ligands. In Transition Metal Complexes of Neutral $\eta 1$-Carbon Ligands; SpringerVerlag: Berlin, 2010; Vol. 30, pp 49-92.

(3) Zhang, X. F.; Sun, M. J.; Cao, Z. X. Theoretical study on interactions of $\mathrm{N}$-heterocyclic carbene with the bare first-row transition metals. Theor. Chem. Acc. 2016, 135, 163-174.

(4) (a) Heinemann, C.; Müller, T.; Apeloig, Y.; Schwarz, H. On the Question of Stability, Conjugation, and "Aromaticity" in imidazole-2ylidenes and their Silicon analogs. J. Am. Chem. Soc. 1996, 118, 20232038. (b) Boehme, C.; Frenking, G. Electronic structure of stable carbenes, silylenes, and germylenes. J. Am. Chem. Soc. 1996, 118, 20392046. (c) Hillier, A. C.; Sommer, W. J.; Yong, B. S.; Petersen, J. L.; Cavallo, L.; Nolan, S. P. A Combined experimental and theoretical study examining the binding of $\mathrm{N}$-Heterocyclic carbenes (NHC) to the $\mathrm{Cp} * \mathrm{RuCl}\left(\mathrm{Cp}^{*}=\eta 5-\mathrm{C} 5 \mathrm{Me} 5\right)$ moiety: Insight into stereoelectronic differences between unsaturated and saturated NHC ligands. Organometallics 2003, 22, 4322-4326. (d) Dröge, T.; Glorius, F. The measure of all rings-N-Heterocyclic carbenes. Angew. Chem., Int. Ed. 2010, 49, 6940-6952.

(5) Petz, W.; Neumüller, B.; Klein, S.; Frenking, G. Syntheses and crystal structures of $[\mathrm{Hg}\{\mathrm{C}(\mathrm{PPh} 3) 2\} 2][\mathrm{Hg} 2 \mathrm{I} 6]$ and $[\mathrm{Cu}\{\mathrm{C}(\mathrm{PPh} 3)$ 2\}2]I and comparative theoretical study of carbene complexes $[\mathrm{M}(\mathrm{NHC}) 2]$ with carbone complexes $[\mathrm{M}\{\mathrm{C}(\mathrm{PH} 3) 2\} 2](\mathrm{M}=\mathrm{Cu}+$, $\mathrm{Ag}+, \mathrm{Au}+, \mathrm{Zn} 2+, \mathrm{Cd} 2+, \mathrm{Hg} 2+)$. Organometallics 2011, 30, 3330-3339. (6) Öfele, K. 1,3-Dimethyl-4-imidazolinyliden-(2)-pentacarbonylchrom ein neuer übergangsmetall-carben-komplex. J. Organomet. Chem. 1968, 12, P42-P43.

(7) Wanzlick, H.-W.; Schönherr, H.-J. Direct synthesis of a Mercury salt-carbene complex. Angew. Chem., Int. Ed. 1968, 7, 141-142.

(8) Arduengo, A. J., III; Harlow, R. L.; Kline, M. A stable crystalline carbene. J. Am. Chem. Soc. 1991, 113, 361-363.

(9) Hindi, K. M.; Panzner, M. J.; Tessier, C. A.; Cannon, C. L.; Youngs, W. J. The medicinal applications of imidazolium carbene-metal complexes. Chem. Rev. 2009, 109, 3859-3884.

(10) Liu, W.; Gust, R. Update on metal N-heterocyclic carbene complexes as potential anti-tumor metallodrugs. Coord. Chem. Rev. 2016, 329, 191-213.

(11) Oehninger, L.; Rubbiani, R.; Ott, I. N-Heterocyclic carbene metal complexes in medicinal chemistry. Dalton Trans. 2013, 42, 3269-3284.

(12) Hu, C.; Li, X.; Wang, W.; Zhang, R.; Deng, L. Metal-Nheterocyclic carbene complexes as anti-tumor agents. Curr. Med. Chem. 2014, 21, 1220-1230.

(13) Cisnetti, F.; Gibard, C.; Gautier, A. Post-functionalization of metal-NHC complexes: A useful toolbox for bio-organometallic chemistry (and beyond)? J. Organomet. Chem. 2015, 782, 22-30.

(14) Aher, S. B.; Muskawar, P. N.; Thenmozhi, K.; Bhagat, P. R. Recent developments of metal N-heterocyclic carbenes as anticancer agents. Eur. J. Med. Chem. 2014, 81, 408-419.

(15) Liu, W.; Gust, R. Metal N-heterocyclic carbene complexes as potential antitumor metallodrugs. Chem. Soc. Rev. 2013, 42, 755-773.

(16) Cisnetti, F.; Gautier, A. Metal/N-Heterocyclic carbene complexes: opportunities for the development of anticancer metallodrugs. Angew. Chem., Int. Ed. Engl. 2013, 52, 11976-11978.
(17) Budagumpi, S.; Haque, R. A.; Endud, S.; Rehman, G. U.; Salman, A. W. Biologically relevant silver(I)-N-Heterocyclic carbene complexes: synthesis, structure, intramolecular interactions, and applications. Eur. J. Inorg. Chem. 2013, 2013, 4367-4388.

(18) Patil, S. A.; Patil, S. A.; Patil, R.; Keri, R. S.; Budagumpi, S.; Balakrishna, G. R.; Tacke, M. N-heterocyclic carbene metal complexes as bio-organometallic antimicrobial and anticancer drugs. Future Med. Chem. 2015, 7, 1305-1333.

(19) Hemmert, C.; Gornitzka, H. Luminescent bioactive NHC-metal complexes to bring light into cells. Dalton Trans. 2016, 45, 440-447.

(20) Zhou, X.; Zhou, L. A theoretical study on the anticancer drug $\mathrm{Au}(\mathrm{I}) \mathrm{N}$-heterocyclic carbine complexes $\left[\left(\mathrm{R}_{2} \mathrm{Im}\right)_{2} \mathrm{Au}\right]^{+}(\mathrm{R}=\mathrm{Me}, \mathrm{Et}$, i$\mathrm{Pr}$, and $\mathrm{n}-\mathrm{Pr}$ ) binding to cysteine and selenocysteine residues. Theor. Chem. Acc. 2016, 135, 1-12.

(21) Alex, J.; Ghosh, P. Fascinating frontiers of N/O-functionalized $\mathrm{N}$-heterocyclic carbene chemistry: from chemical catalysis to biomedical application. Dalton Trans. 2010, 39, 7183-7206.

(22) Gautier, A.; Cisnetti, F. Advances in metal-carbene complexes as potent anti-cancer agents. Metallomics 2012, 4, 23-32.

(23) Zhang, P.; Sadler, P. J. Advances in the design of organometallic anticancer complexes. J. Organomet. Chem. 2017, 839, 5-14.

(24) Hickey, J. L.; Ruhayel, R. A.; Barnard, P. J.; Baker, M. V.; BernersPrice, S. J.; Filipovska, A. Mitochondria-Targeted Chemotherapeutics: The rational design of Gold(I) N-Heterocyclic carbene complexes that are selectively toxic to cancer cells and target protein selenols in the preference to thiol. J. Am. Chem. Soc. 2008, 130, 12570-12571.

(25) Wedlock, L. E.; Berners-Price, S. J. Recent advances in mapping the sub-cellular distribution of metal-based anticancer drugs. Aust. J. Chem. 2011, 64, 692-704.

(26) Mayer, H. A.; Kaska, W. C. Stereochemical control of transition metal complexes by polyphosphine ligands. Chem. Rev. 1994, 94, $1239-1272$.

(27) Hermann, M.; Frenking, G. Carbones as Ligands in Novel MainGroup Compounds $\mathrm{E}\left[\mathrm{C}(\mathrm{NHC})_{2}\right]_{2}\left(\mathrm{E}=\mathrm{Be}, \mathrm{B}^{+}, \mathrm{C}^{2+}, \mathrm{N}^{3+}, \mathrm{Mg}, \mathrm{Al}^{+}, \mathrm{Si}^{2+}\right.$, $\left.\mathrm{P}^{3+}\right)$ : A Theoretical Study. Chem.-Eur. J. 2017, 23, 3347-3356.

(28) de Fremont, P.; Stevens, E. D.; Eelman, M. D.; Fogg, D. E.; Nolan, S. P. Synthesis and characterization of Gold(I) N-Heterocyclic carbene complexes bearing biologically compatible moieties. Organometallics 2006, 25, 5824-5828.

(29) Frisch, M. J.; Trucks, G. W.; Schlegel, H. B.; Scuseria, G. E.; Robb, M. A.; Cheeseman, J. R.; Scalmani, G.; Barone, V.; Mennucci, B.; Petersson, G. A.; Nakatsuji, H.; Caricato, M.; Li, X.; Hratchian, H. P.; Izmaylov, A. F.; Bloino, J.; Zheng, G.; Sonnenberg, J. L.; Hada, M.; Ehara, M.; Toyota, K.; Fukuda, R.; Hasegawa, J.; Ishida, M.; Nakajima, T.; Honda, Y.; Kitao, O.; Nakai, H.; Vreven, T.; Montgomery, J. A.; Peralta, J. E.; Ogliaro, F.; Bearpark, M.; Heyd, J. J.; Brothers, E.; Kudin, K. N.; Staroverov, V. N.; Keith, T.; Kobayashi, R.; Normand, J.; Raghavachari, K.; Rendell, A.; Burant, J. C.; Iyengar, S. S.; Tomasi, J.; Cossi, M.; Rega, N.; Millam, J. M.; Klene, M.; Knox, J. E.; Cross, J. B.; Bakken, V.; Adamo, C.; Jaramillo, J.; Gomperts, R.; Stratmann, R. E.; Yazyev, O.; Austin, A. J.; Cammi, R.; Pomelli, C.; Ochterski, J. W.; Martin, R. L.; Morokuma, K.; Zakrzewski, V. G.; Voth, G. A.; Salvador, P.; Dannenberg, J. J.; Dapprich, S.; Daniels, A. D.; Farkas, O.; Foresman, J. B.; Ortiz, J. V.; Cioslowski, J.; Fox, D. J. Gaussian 09; Gaussian, Inc.: Wallingford, CT, 2010.

(30) Bader, R. F. W. Atoms in Molecules: A Quantum Theory; Oxford University Press: Oxford, 1990.

(31) Glendening, E. A.; Reed, A. E.; Carpenter, J. E.; Weinhold, F. NBO, version 3.1; Gaussian Inc.: Pittsburgh, 2003.

(32) Bayat, M.; Soltani, E. Stabilization of group 14 tetrylene compounds by N-heterocyclic carbene: A theoretical study. Polyhedron 2017, 123, 39-46.

(33) Nemcsok, D.; Wichmann, K.; Frenking, G. The Significance of $\pi$ Interactions in Group 11 complexes with N-Heterocyclic carbenes. Organometallics 2004, 23, 3640-3646.

(34) Bayat, M.; Sedghi, A.; Ebrahimkhani, L.; Sabounchei, SJ NHeterocyclic carbene or phosphorus ylide: which one forms a stronger bond with group 11 metals? A theoretical study. Dalton Trans. 2016, 46, 207-220. 
(35) Popelier, P. L. A. Atoms in Molecules: An Introduction; Pearson Education, Prentice Hall: Harlow, England, 2000.

(36) Fukui, K. Recognition of stereochemical paths by orbital interaction. Acc. Chem. Res. 1971, 4, 57-64.

(37) Boys, S. F.; Bernardi, F. The calculation of small molecular interactions by the differences of separate total energies. Some procedures with reduced errors. Mol. Phys. 1970, 19, 553-566.

(38) Morokuma, K. Molecular orbital studies of hydrogen bonds. III. $\mathrm{C}=\mathrm{O} \cdots \mathrm{H}-\mathrm{O}$ Hydrogen bond in $\mathrm{H}_{2} \mathrm{CO} \cdots \mathrm{H}_{2} \mathrm{O}$ and $\mathrm{H}_{2} \mathrm{CO} \cdots 2 \mathrm{H} 2 \mathrm{O} . J$. Chem. Phys. 1971, 55, 1236-1244.

(39) Ziegler, T.; Rauk, A. Carbon monoxide, carbon monosulfide, molecular nitrogen, phosphorus trifluoride, and methyl isocyanide as $\sigma$ donors and $\pi$ acceptors. A theoretical study by the Hartree-Fock-Slater transition-statemethod. Inorg. Chem. 1979, 18, 1755-1759.

(40) Ziegler, T.; Rauk, A. A theoretical study of the ethylene-metal bond in complexes between copper(1+), silver(1+), gold(1+), platinum $(0)$ or platinum $(2+)$ and ethylene, based on the HartreeFock-Slater transition-state method. Inorg. Chem. 1979, 18, 15581565.

(41) Mitoraj, M.; Michalak, A. Donor-Acceptor properties of ligands from the natural orbitals for chemical valence. Organometallics 2007, 26, 6576-6580.

(42) Mitoraj, M.; Michalak, A. Applications of natural orbitals for chemical valence in a description of bonding in conjugated molecules. J. Mol. Model. 2008, 14, 681-687.

(43) Frenking, G.; Shaik, S. The Chemical Bond: Fundamental Aspects of Chemical Bonding; Wiley-VCH: Weinheim, 2014.

(44) Bickelhaupt, F. M.; Baerends, E. J. Kohn-Sham density functional theory: Predicting and understanding chemistry. Rev. Comput. Chem. 2000, 15, 1-86. 